\title{
Endogenous Interferon $\gamma$ Directly Regulates Neural Precursors in the Non-Inflammatory Brain
}

\author{
Li Li, Tara L. Walker, Ying Zhang, Eirinn W. Mackay, and Perry F. Bartlett \\ Queensland Brain Institute, The University of Queensland, Brisbane, Queensland 4072, Australia
}

\begin{abstract}
Although a number of growth factors have been shown to be involved in neurogenesis, the role of inflammatory cytokines remains relatively unexplored in the normal brain. Here we investigated the effect of interferon gamma (IFN $\gamma$ ) in the regulation of neural precursor (NP) activity in both the developing and the adult mouse brain. Exogenous IFN $\gamma$ inhibited neurosphere formation from the wild-type neonatal and adult subventricular zone (SVZ). More importantly, however, these effects were mirrored in vivo, with mutant mice lacking endogenous IFN $\gamma$ displaying enhanced neurogenesis, as demonstrated by an increase in proliferative bromodeoxyuridinelabeled cells in the SVZ and an increased percentage of newborn neurons in the olfactory bulb. Furthermore, NPs isolated from IFN $\gamma$ null mice exhibited an increase in self-renewal ability and in the capacity to produce differentiated neurons and oligodendrocytes. These effects resulted from the direct action of IFN $\gamma$ on the NPs, as determined by single-cell assays and the fact that nearly all the neurospheres were derived from cells positive for major histocompatibility complex class I antigen, a downstream marker of IFN $\gamma$-mediated activation. Moreover, the inhibitory effect was ameliorated in the presence of SVZ-derived microglia, with their removal resulting in almost complete inhibition of NP proliferation. Interestingly, in contrast to the results obtained in the adult, exogenous IFN $\gamma$ treatment stimulated neurosphere formation from the embryonic brain, an effect that was mediated by sonic hedgehog. Together these findings provide the first direct evidence that IFN $\gamma$ acts as a regulator of the active NP pool in the non-inflammatory brain.
\end{abstract}

\section{Introduction}

New neurons are constitutively generated throughout life from the endogenous pool of neural precursors (NPs) in the stem cell niches of the adult brain [i.e., subventricular zone (SVZ) and hippocampus]. This process is highly modulated by both intrinsic programs and extrinsic factors in these neurogenic niches (Lledo et al., 2006; Ninkovic and Götz, 2007). Moreover, the interactions between NPs and their cellular environment, including astrocytes, endothelial cells, and microglia, play an important role in neurogenesis (Song et al., 2002; Fuchs et al., 2004; Shen et al., 2004; Walton et al., 2006). Multiple factors function in concert to decide NP fate under both normal and pathological conditions. A series of stimulatory factors have been shown to regulate neurogenesis in either the SVZ or the hippocampus, including brain-derived neurotrophic factor (Chen et al., 2007), erythropoietin (Shingo et al., 2001), epithelial growth factor (EGF) (Reynolds et al., 1992), basic fibroblast growth factor (bFGF) (Murphy et al., 1990; Richards et al., 1992; Leker et al., 2007), and heparin growth factor (Kokuzawa et al., 2003). However, factors such as bone morphogenetic proteins (Shou et al.,

Received Nov. 16, 2009; revised March 25, 2010; accepted May 13, 2010

This work was funded by a National Health and Medical Research Council (NHMRC) program grant (P.F.B.).P.F.B. was supported by an Australian Research Council Federation Fellowship and L.L. by an NHMRC Peter Doherty Fellowship. We thank Prof. lan Frazer for kindly supplying the IFN $\gamma$ mutant mice. We also thank Prof. David Hume for providing the eGFP- cfms transgenic mice. Special thanks go to Geoffrey Osborne, Virginia Nink, and Damien Gardiner for FACS analysis, Rowan Tweedale for assistance with this manuscript, the animal house staff for the care of the mice, Jane Ellis and Kathryn French for help with histology, and Diane Muller for assistance in microscopy.

Correspondence should be addressed to Prof. Perry Bartlett, Queensland Brain Institute, The University of Queensland, Brisbane, Queensland 4072, Australia. E-mail: p.bartlett@uq.edu.au.

DOI:10.1523/JNEUROSCI.5691-09.2010

Copyright $\odot 2010$ the authors $\quad 0270-6474 / 10 / 309038-13 \$ 15.00 / 0$
1999), ephrin A2 (Holmberg et al., 2005; Jiao et al., 2008), and nitric oxide (Packer et al., 2003), which exert a negative effect, have been found to be equally important for the maintenance of the stem cell pool. Balancing these factors is important not only for regulating normal homeostasis in the neurogenic niche but also for adjusting the equilibrium under pathological conditions to mediate brain repair.

Similarly, inflammatory responses appear to have stimulatory and/or inhibitory effects on the activation of endogenous NPs (Nakatomi et al., 2002; Mokrý et al., 2003; Monje and Palmer, 2003; Wiltrout et al., 2007), which are believed to be associated with microglial activation (Ekdahl et al., 2003; Monje et al., 2003; Liu et al., 2007). It has been suggested that the balance between secreted molecules with proinflammatory and anti-inflammatory actions determines whether neurogenesis is promoted or inhibited (Ekdahl et al., 2009). Proinflammatory cytokines, such as interleukin- 6 and interleukin- $1 \beta$, released from activated microglia, are anti-neurogenic (Vallières et al., 2002; Monje et al., 2003; Koo and Duman 2008), whereas anti-inflammatory cytokines, such as interleukin-4, induce microglia to secrete insulin-like growth factor-1 (IGF-1), thereby promoting neurogenesis (Butovsky et al., 2006).

Interferon gamma (IFN $\gamma$ ), a "proinflammatory" cytokine, is a major player in the pathology of the neuroinflammatory response, during which it is released from activated microglia (Li et al., 2001; Bogdan and Schleicher, 2006). By mimicking the inflammatory scenario in vivo, Butovsky et al. (2006) have shown that cultured microglia exposed to lysophosphatidic acid and stimulated with IFN $\gamma$ support neurogenesis. Nevertheless, to date, no evidence exists to demonstrate that IFN $\gamma$ plays a role in 
neurogenesis in the non-inflammatory brain, although it has been shown that low levels of IFN $\gamma$ can be produced by astrocytes, fibroblasts, and cerebrovascular endothelial cells under normal conditions (Rady et al., 1995; De Simone et al., 1998; Wei et al., 2000). In the present study, we therefore investigated the effect of IFN $\gamma$ on NP activity and neurogenesis. Our results reveal that IFN $\gamma$ has a major regulatory effect on NP activity in both the developing and the adult mouse brain.

\section{Materials and Methods}

Animals. Embryonic day 12 (E12), postnatal day 2 (P2), and adult (3-4 month old) C57BL/6 mice were used in this study. IFN $\gamma^{-1-}$ mice were backcrossed over 10 generations to the C57BL/6 background by The Jackson Laboratory. Enhanced green fluorescent protein (eGFP)-colony stimulating factor 1 receptor (cfms) transgenic mice, in which the cfms promoter drives expression of eGFP in cells of macrophage lineage, were kindly provided by Professor David Hume (Institute for Molecular Bioscience, The University of Queensland, Brisbane, Queensland, Australia). Bax-deficient $\left(\mathrm{Bax}^{-/-}\right)$mice were maintained on a $\mathrm{C} 57 \mathrm{BL} / 6$ background (Sun et al., 2004). Sibling animals were collected and individually genotyped by PCR as described previously (Knudson et al., 1995). All experiments were conducted according to the Australian Code of Practice for the Care and Use of Animals for Scientific Purposes and with approval from the University of Queensland Animal Ethics Committee.

Total RNA isolation, cDNA synthesis, and quantitative PCR. Total RNA was isolated from E12 mesencephalon and telencephalon and P2 and adult SVZ using TriZol RNA isolation reagent (Invitrogen) according to the instructions of the manufacturer. Reverse transcription was performed to synthesize cDNA using the superscript II system (Invitrogen). Quantitative PCR (Q-PCR) was performed using a Platinum SYBR Green Q-PCR Supermix UDG kit (Invitrogen). Q-PCR primers were designed to amplify regions of the IFN $\gamma$ gene and its receptor, with each primer set designed to amplify a product of $\sim 200 \mathrm{bp}$. The PCR program was $50^{\circ} \mathrm{C}$ for $2 \mathrm{~min}$ and $94^{\circ} \mathrm{C}$ for $2 \mathrm{~min}$, followed by 45 cycles of $94^{\circ} \mathrm{C}$ for $30 \mathrm{~s}, 60^{\circ} \mathrm{C}$ for $30 \mathrm{~s}$, and $72^{\circ} \mathrm{C}$ for $30 \mathrm{~s}$. All gene amplification was standardized to an $18 \mathrm{~S}$ ribosomal RNA control, and no reverse transcription controls were also run with the $18 \mathrm{~S}$ primers to ensure that there was no amplification from genomic DNA. Gene expression was quantified as fold differences. Each sample was tested in triplicate, and data from three independent experiments were used to calculate the means and SDs. The primer sequences were as follows: IFN $\gamma$ forward, $5^{\prime}$-aagacaatcaggccatcagc- $3^{\prime}$; IFN $\gamma$ reverse, $5^{\prime}$-ttcctgaggctggattccgg- $3^{\prime}$; IFN $\gamma$ receptor forward, $5^{\prime}$-cctggcctggagatcaggag- $3^{\prime}$; and IFN $\gamma$ receptor reverse, $5^{\prime}$-ccgtatgtttcgtatgtagg- $3^{\prime}$.

Neurosphere culture. The mesencephalon and telencephalon of E12 mice or the SVZ or olfactory bulbs of P2 and adult brains were dissected in HEPES-buffered minimum essential medium (HEM), consisting of minimum essential medium (Invitrogen), supplemented with $16 \mathrm{~mm}$ HEPES (Sigma-Aldrich) and $100 \mathrm{U} / \mathrm{ml}$ penicillin/streptomycin (Invitrogen). The tissues were minced and digested with $0.05 \%$ trypsin-EDTA (Invitrogen) and incubated at $37^{\circ} \mathrm{C}$ for $7 \mathrm{~min}$, followed by the addition of $0.014 \%(\mathrm{w} / \mathrm{v})$ trypsin inhibitor (type I-S from soybean; Sigma-Aldrich) dissolved in HEM. They were then centrifuged at $700 \mathrm{rpm}$ for $7 \mathrm{~min}$, after which the pellets were resuspended in $200 \mu \mathrm{l}$ of $0.1 \mathrm{M}$ PBS and triturated into a single-cell suspension. The cells were washed with EGF + FGF $(\mathrm{E}+\mathrm{F})$ medium containing mouse NeuroCult neural stem cell (NSC) basal medium, mouse NeuroCult NSC proliferation supplements (StemCell Technologies), $2 \%$ bovine serum albumin (Roche), $2 \mu \mathrm{g} / \mathrm{ml}$ heparin (Sigma-Aldrich), $20 \mathrm{ng} / \mathrm{ml}$ purified mouse receptor grade EGF (BD Biosciences), and $10 \mathrm{ng} / \mathrm{ml}$ recombinant bFGF (Roche). They were then filtered through a $40 \mu \mathrm{m}$ cell filter (BD Biosciences), plated in 96-well plates, and cultured in $\mathrm{E}+\mathrm{F}$ medium in a humidified incubator at $37^{\circ} \mathrm{C}$. Recombinant murine IFN $\gamma$ (Millipore Bioscience Research Reagents) was added into the $\mathrm{E}+\mathrm{F}$ medium at different doses as appropriate. Sonic hedgehog (Shh) (R \& D Systems) at a concentration of $5 \mathrm{~nm}$ was used in some neurosphere cultures from E12 neural cells as indicated. A specific inhibitor of Shh, cyclopamine (Toronto Research Biochemicals), was used at $5 \mu \mathrm{M}$. The number and size of the SVZ neurospheres were deter- mined $7 \mathrm{~d}$ after plating, whereas olfactory bulb neurospheres were assessed after $10 \mathrm{~d}$.

For clonal assays, primary SVZ cells were diluted in E + F medium with or without $50 \mathrm{ng} / \mathrm{ml}$ IFN $\gamma$ and plated into 20 96-well plates (one cell per well). The next day, after microscopic confirmation, five representative wells per plate containing a single cell were marked, and the neurospheres were counted after $10 \mathrm{~d}$. For the clonal assay of primary neurosphere cells, the primary neurospheres were dissociated into a single-cell suspension, and the resultant cells were plated in 96-well plates at one cell per well in $200 \mu \mathrm{l}$ of medium, with or without $50 \mathrm{ng} / \mathrm{ml} \mathrm{IFN} \gamma$. The resultant secondary neurospheres were counted after $7 \mathrm{~d}$.

For the limiting dilution assay, adult SVZ cells were plated at reducing densities in 96-well plates in $200 \mu \mathrm{l}$ of $\mathrm{E}+\mathrm{F}$ medium, with or without 50 $\mathrm{ng} / \mathrm{ml}$ IFN $\gamma$. Cells were plated at 640, 320, 160, 80, 40, 20, 10, 5, and 1 cell per well. After $7 \mathrm{~d}$ in vitro, the number of wells that did not contain neurospheres was quantified. The data were then log transformed and plotted against plating density. A linear regression was performed and a straight line fitted to the data.

To confirm that IFN $\gamma$-induced inhibition of neurosphere formation was not attributable to an increase in cell death, primary neurosphere cultures were also performed using $\mathrm{Bax}^{-/-}$mice that lack programmed cell death. The SVZ was dissected from the Bax-deficient animals and their wild-type littermates, and neurospheres were cultured as described above. Furthermore, to ensure that no cell death occurs when Bax ${ }^{-1-}$ SVZ cells are cultured in vitro, primary neurospheres were collected from both $\mathrm{Bax}^{-/-}$and wild-type mice and dissociated into a single-cell suspension. The cells were then cultured at a density of $2.5 \times 10^{4}$ cells in a T25 flask in $\mathrm{E}+\mathrm{F}$ medium, with or without $50 \mathrm{ng} / \mathrm{ml} \mathrm{IFN} \gamma$, for $4 \mathrm{~d}$. These secondary neurospheres were then enzymatically dissociated into a single-cell suspension, and viable cell concentration was determined by staining triplicate samples with trypan blue and counting using a hemocytometer.

Long-term passaging of IFN $\gamma^{-/-}$and IFN $\gamma^{+/+}$neurospheres. Adult SVZ cells from IFN $\gamma^{-1-}$ and $I F N \gamma^{+/+}$mice were cultured through multiple passages using the neurosphere assay as described previously (Bull and Bartlett, 2005). The primary neurospheres generated from IFN $\gamma^{-/-}$ and $\mathrm{FNN}^{+/+}$SVZ were collected and enzymatically dissociated to generate a single-cell suspension. This was considered as passage zero (P0). At each passage, cells originating from $I F N \gamma^{-1-}$ and $I F N \gamma^{+/+}$neurospheres were replated into six-well plates at a cell density of 15,000 cells in $5 \mathrm{ml}$ of $\mathrm{E}+\mathrm{F}$ medium, with or without $50 \mathrm{ng} / \mathrm{ml} \mathrm{IFN} \gamma$.

Differentiation of primary neurospheres. Neurospheres established from the SVZ of age-matched IFN $\gamma^{-/-}$and $I F N \gamma^{+/+}$mice were plated onto glass coverslips coated with poly-L-ornithine (Sigma) and laminin (natural mouse; Invitrogen) in neurosphere differentiation medium containing mouse NeuroCult NSC basal medium, mouse NeuroCult NSC proliferation supplements, and $1 \%$ fetal calf serum (FCS). To quantitatively analyze the multipotentiality of the neurospheres, individual $I F N \gamma^{-1-}$ and IFN $\gamma^{+/+}$neurospheres between 180 and $200 \mu \mathrm{m}$ in diameter were selected. Because of the smaller size of IFN $\gamma$-treated neurospheres, neurospheres ranging from 70 to $100 \mu \mathrm{m}$ in diameter were selected from both IFN $\gamma$-treated cultures and non-IFN $\gamma$-treated cultures. Neurospheres were allowed to differentiate for $8 \mathrm{~d}$ in a $5 \% \mathrm{CO}_{2} /$ $37^{\circ} \mathrm{C}$ tissue culture incubator. The differentiated neurospheres were then analyzed for the acquisition of differentiation markers by immunohistochemistry, as described below.

Immunohistochemistry of differentiated neurospheres. To assess the differentiation potential of undissociated neurospheres, coverslips containing the neurospheres were rinsed gently with PBS and fixed with $4 \%$ paraformaldehyde (PFA) for $20 \mathrm{~min}$ at room temperature (RT). The neurospheres were then rinsed three times with PBS to remove the PFA, and the fixed neurospheres were incubated in blocking solution (5\% FCS and $5 \%$ normal goat serum in PBS) for $1 \mathrm{~h}$ at $37^{\circ} \mathrm{C}$. The blocking solution was removed, and the coverslips were incubated overnight at $4^{\circ} \mathrm{C}$ with anti-O4 antibody (diluted 1:30 in blocking solution; mouse anti-O4 IgM hybridoma) (Bansal et al., 1988) to specifically label oligodendrocytes. The neurospheres were rinsed three times with PBS, after which they were incubated with Alexa Fluor 488-conjugated goat anti-mouse IgM (diluted 1:1000 in blocking solution; Invitrogen) for $30 \mathrm{~min}$ at $37^{\circ} \mathrm{C}$. The 
neurospheres were then rinsed three times with PBS and permeabilized by incubating for $1 \mathrm{~h}$ in blocking solution containing $0.1 \%$ Triton X-100, after which the blocking solution was replaced with fresh solution containing a mix of anti- $\beta$ III-tubulin mouse IgG monoclonal antibody (diluted 1:2000; Promega) and rabbit anti-bovine glial fibrillary acidic protein (GFAP) polyclonal antibody (diluted 1:500; Dako) and incubated overnight at $4^{\circ} \mathrm{C}$. The neurospheres were rinsed in PBS and then incubated for $30 \mathrm{~min}$ at $37^{\circ} \mathrm{C}$ in blocking solution containing a mix of Alexa Fluor 568-conjugated goat anti-mouse antibody (1:1000; Invitrogen) and Alexa Fluor 488-conjugated anti-rabbit antibody (1:1000; Invitrogen). After washing with PBS, the slides were coverslipped with fluorescence mounting medium (Dako).

To count the number of $\beta$ III-tubulin-, O4-, and GFAP-positive cells in differentiated neurospheres, size-matched differentiated neurospheres were selected. At least eight fields of view per neurosphere were randomly chosen at the $400 \times$ magnification, and only cells with several processes stained for $\mathrm{O} 4$ were counted as $\mathrm{O} 4$-positive oligodendrocytes. $\beta$ IIITubulin-, O4-, and GFAP-positive cells were counted from the same field. Data were expressed as the percentage of cells positive for each marker among the total number of labeled cells.

Induction of major histocompatibility complex class I antigen with IFN $\gamma$. Single-cell suspensions of E12 mesencephalon and telencephalon and adult SVZ were induced to express major histocompatibility complex class I (MHCI) antigen by short-term incubation in $\mathrm{E}+\mathrm{F}$ medium containing $10 \mathrm{ng} / \mathrm{ml} \mathrm{IFN} \gamma$, a protocol shown not to affect the level of neurosphere formation. As a control, the same number of cells was also incubated with E + F medium alone. Twenty-four hours after incubation, single-cell suspensions were labeled by a direct immunofluorescence method as outlined below. At least three experiments were performed.

Isolation of MHCI-positive and-negative cells by fluorescence-activated cell sorting. MHCI-positive cells were labeled with a fluorescein isothiocyanate (FITC)-conjugated mouse anti-mouse $\mathrm{H}-2 \mathrm{~K}^{\mathrm{b}}$ monoclonal antibody, which exclusively recognizes the $\mathrm{H}-2 \mathrm{~K}^{\mathrm{b}} \mathrm{MHCI}$ alloantigen (clone AF6-88.5; BD Biosciences), at a concentration of $1 \mu \mathrm{g} / \mathrm{ml}$ for $60 \mathrm{~min}$ at RT. After the incubation, the single-cell suspensions were washed with 5 $\mathrm{ml}$ of PBS. Propidium iodide was added to the final wash to label dead cells. The cells were then resuspended in E + F medium and sorted on a FACSVantage cell sorter (BD FACSVantage SE Diva option). Gates were selected to exclude cell debris, clumps, and dead cells. The parameters for separating FITC- $\mathrm{H}-2 \mathrm{~K}^{\mathrm{b}}$-positive (MHCI-positive) from FITC- $\mathrm{H}-2 \mathrm{~K}^{\mathrm{b}}$ negative (MHCI-negative) populations were then determined by comparing the fluorescence profiles of cells incubated in the presence of 10 $\mathrm{ng} / \mathrm{ml}$ IFN $\gamma$ with those of non-IFN $\gamma$-treated cells. When isolation of MHCI-positive cells from the eGFP-cfms transgenic mice brain was required, a fluorescein $\mathrm{R}$-phycoerytherin (PE)-conjugated mouse antimouse $\mathrm{H}-2 \mathrm{~K}^{\mathrm{b}}$ monoclonal antibody (clone AF6-88.5; BD Biosciences) at a concentration of $1 \mu \mathrm{g} / \mathrm{ml}$ was used. Two negative controls were included. One control was cells incubated in parallel with experimental samples but without FITC- $\mathrm{H}-2 \mathrm{~K}^{\mathrm{b}}$ staining, and the other was cells stained with mouse isotype $\operatorname{IgG}_{2 \alpha}(1 \mu \mathrm{g} / \mathrm{ml}$; Millipore Bioscience Research Reagents). Because MHCI-positive cells were mainly found in the samples treated with IFN $\gamma$ and not in those treated with $\mathrm{E}+\mathrm{F}$ medium alone, the positive and negative populations at the different ages were only sorted from the sample treated with IFN $\gamma$, and plated into 96-well plates containing $200 \mu \mathrm{l}$ of $\mathrm{E}+\mathrm{F}$ medium. To estimate the actual number of cells per well, cells in three representative wells per population were counted $4 \mathrm{~h}$ after plating. The resultant neurospheres were counted after incubation for $7 \mathrm{~d}$.

Isolation of eGFP-negative cells from SVZ of eGFP-cfms transgenic mice by fluorescence-activated cell sorting. The SVZ of eGFP-cfms mice was dissected and triturated into a single-cell suspension as described above. Cells were divided into two fractions: one remained unsorted, whereas the remaining cells were divided into eGFP-positive and eGFP-negative populations by fluorescence-activated cell sorting (FACS) after excluding cell debris and clumps. The sorted eGFP-negative cells and unsorted cells were cultured in E + F medium, with or without $50 \mathrm{ng} / \mathrm{ml}$ IFN $\gamma$. The cells were then plated at 2000 cells/200 $\mu$ l per well in 96 -well plates. The resultant primary neurospheres were counted $7 \mathrm{~d}$ after plating, with the experiments being performed three times.

Bromodeoxyuridine injection. To assess cell proliferation in the SVZ of the IFN $\gamma^{+/+}$and $I F N \gamma^{-/-}$brains, mice of each genotype $(n=3)$ were given a single intraperitoneal injection of $100 \mathrm{mg} / \mathrm{kg}$ bromodeoxyuridine (BrdU) (Sigma) and perfused $1 \mathrm{~h}$ after injection. To assess neurogenesis in the olfactory bulb, five injections spaced every $2 \mathrm{~h}$ were administered to mice of each genotype $(n=4) 4$ weeks before they were killed. For assessment of migration of proliferating cells along the rostral migratory stream into the olfactory bulb, two injections of BrdU $4 \mathrm{~h}$ apart were given $3 \mathrm{~d}$ before the animals ( $n=3$ per genotype) were killed.

Tissue processing and immunohistochemistry. Animals were perfused transcardially with PBS, followed by cold $4 \%$ PFA in PBS. The brains were then removed and postfixed overnight by immersion in $4 \%$ PFA in $\mathrm{PBS}$ at $4^{\circ} \mathrm{C}$. After postfixation, the brains were cryoprotected by incubation overnight in $30 \% \mathrm{w} / \mathrm{v}$ sucrose in PBS until they sank. They were subsequently embedded in OCT compound (Tissue-Tek; Sakura Finetechnical) and frozen in an ethanol bath on dry ice. Coronal or sagittal sections (40 $\mu \mathrm{m})$ were then cut using a microtome.

For coronal SVZ, sections were processed for BrdU immunohistochemistry. Coronal olfactory bulb sections were processed for BrdU and neuronal-specific nuclear protein (NeuN) double immunohistochemistry. The sections were pretreated with $0.2 \%$ Triton X-100 in PBS for $2 \mathrm{~h}$ at RT, followed by DNA denaturation with $2 \mathrm{~N} \mathrm{HCl}$ for $30 \mathrm{~min}$ at $37^{\circ} \mathrm{C}$. The sections were then washed in PBS and incubated in blocking solution containing 10\% normal goat serum (NGS) and 1\% bovine serum albumin (Invitrogen) in PBS for $60 \mathrm{~min}$ at RT, followed by incubation overnight at $4^{\circ} \mathrm{C}$ with biotin-labeled $\mathrm{BrdU}$ (1:100; Invitrogen) or biotin-labeled BrdU and mouse anti-NeuN (1:100; Millipore Corporation) in PBS containing 1\% NGS, $1 \%$ BSA, and $0.2 \%$ Triton X-100. The sections were next rinsed in PBS three times for $10 \mathrm{~min}$ and subsequently incubated for $1 \mathrm{~h}$ at RT with secondary antibody, either streptavidin, cyanine 3 (Cy3) conjugate (1:500; GE Healthcare) or streptavidin, Cy3 conjugate (1:500; GE Healthcare) and Alexa Fluor 488-conjugated goat anti-mouse IgG (1:500; Invitrogen) and 4'-6diamidino-2-phenylindole (DAPI) (1:1000; Sigma-Aldrich) diluted in blocking solution. After a final rinse with PBS, the slides were coverslipped with mounting medium (Dako) and examined using a Carl Zeiss fluorescence microscope.

To quantitatively analyze the number of BrdU-positive cells in the SVZ, sections were viewed at $400 \times$ magnification on a fluorescence microscope (Carl Zeiss). Images were captured using a digital camera linked to a computer running Axioscope version 4.6 (Carl Zeiss). BrdU-positive SVZ cells were counted in sections taken at four evenly spaced rostrocaudal intervals at $0.26,0.50,0.74$, and $0.98 \mathrm{~mm}$ relative to bregma. For quantitation of the migration, BrdU-positive cells were counted in olfactory bulb sections taken at six evenly spaced intervals per genotype. To determine the percentage of newborn neurons in IFN $\gamma^{+/+}$and IFN $\gamma^{-/-}$ olfactory bulbs, $\sim 500 \mathrm{BrdU}$-positive cells were randomly chosen from the granular cell layer (GCL) of eight olfactory bulbs per genotype. These cells were then scored positive or negative for NeuN, and data were expressed as the percentage of NeuN-positive cells in the total number of BrdU-positive cells.

Colabeling for polysialic acid-neural cell adhesion molecule, GFAP, and DAPI along the SVZ-rostral migratory stream-olfactory bulb axis. Sagittal brain sections ( $40 \mu \mathrm{m}$ thickness) were blocked with PBS containing 10\% NGS and $0.2 \%$ Triton X-100 for $2 \mathrm{~h}$ and then incubated overnight at $4^{\circ} \mathrm{C}$ with mouse monoclonal anti-polysialic acid-neural cell adhesion molecule antibody (1:300; Millipore Corporation) and rabbit polyclonal antiGFAP antibody (1:1000; Dako). After washing with PBS, the sections were incubated with Alexa Fluor 488-conjugated goat anti-mouse IgM (1:500; Invitrogen) and Alexa Fluor 568-conjugated goat anti-rabbit IgG (1:500; Invitrogen) and DAPI (1:1000) for $2 \mathrm{~h}$ at RT. Sagittal sections $0.875 \mathrm{~mm}$ lateral to bregma were chosen for image processing.

Cresyl violet histochemistry for Nissl substance. Frozen coronal sections $(10 \mu \mathrm{m})$ of the olfactory bulb from $I F N \gamma^{-1-}$ and $I F N \gamma^{+/+}$mice were prepared using a cryostat. Nissl substance was revealed by cresyl violet staining. IFN $\gamma^{-/-}$and IFN $\gamma^{+/+}$tissue sections were processed simultaneously to ensure equivalent staining intensity. OCT was first removed by rinsing the slides under running tap water. The sections were then 
A

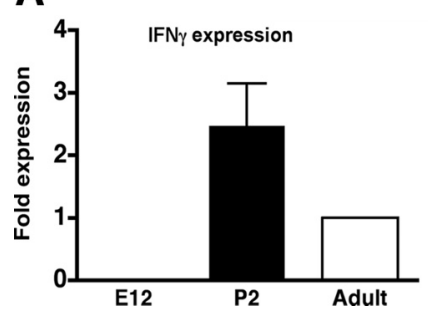

B

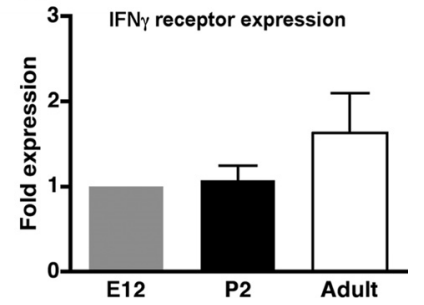

Figure 1. Quantitative PCR detection of IFN $\gamma$ mRNA $(\boldsymbol{A})$ and its receptor mRNA $(\boldsymbol{B})$ in E12 brain and $\mathrm{P} 2$ and adult SVZ. Relative expression was standardized to $18 \mathrm{~S}$ mRNA amplification for each sample. IFN $\gamma$ expression is expressed as fold difference relative to adult sample. IFN $\gamma$ receptor expression is expressed as fold difference relative to E12 sample.

stained with cresyl violet acetate $(0.05 \%$ adjusted to $\mathrm{pH} 4.3$ with glacial acetic acid; ICN Biochemicals) for $8 \mathrm{~min}$, followed by rinsing with tap water for $1 \mathrm{~min}$. The sections were then placed in $95 \%$ ethanol for $1 \mathrm{~min}$, followed by two 1-min washes in $100 \%$ ethanol. The sections were finally incubated in xylene for $10 \mathrm{~min}$ and then mounted using mounting medium (Dako). The cells in the olfactory bulb sections were counted at the median level of the olfactory bulb ( $4.24 \mathrm{~mm}$ relative to bregma) from both $I F N \gamma^{-1-}$ and $I F N \gamma^{+/+}$mice ( $n=3$ in both cases). Cell counts were performed using Axioautomeasure software within Axioscope version 4 (Carl Zeiss). Approximately 100 glomeruli were chosen from mice of each genotype, and the total number of periglomerular layer cells per glomerulus counted.

Measurement of weight and size of olfactory bulb. The olfactory bulbs of $I F N \gamma^{-\prime-}$ and IFN $\gamma^{+/+}$mice were dissected and then weighed and measured separately. Comparisons of olfactory bulb weights and sizes were made between genotypes using the Student's $t$ test.

Data analysis. Data analysis was performed using Prism software (version 4.0c; GraphPad Software). Results were expressed as mean $\pm \mathrm{SE}$ unless otherwise stated. Statistical significance was determined using one-way ANOVA or Student's $t$ tests as appropriate. The level of significance was set at $p<0.05$.

\section{Results}

IFN $\gamma$ and IFN $\gamma$ receptor $\mathrm{mRNAs}$ are expressed in neurogenic areas of the brain

To determine whether IFN $\gamma$ and its receptor are normally expressed in the neurogenic areas of the brain during development and adulthood, we first determined the mRNA levels of IFN $\gamma$ and its receptor in E12 brain and in the SVZ of P2 and adult animals using Q-PCR. IFN $\gamma$ mRNA was not detectable in the E12 brain but was expressed at significant levels in the SVZ at P2 and at slightly lower levels in the adult SVZ (Fig. 1A). IFN $\gamma$ receptor mRNA was detected at significant levels at all stages examined (Fig. $1 B$ ).

\section{IFN $\gamma$ inhibits $\mathrm{P} 2$ and adult NP activity in vitro}

Given that both IFN $\gamma$ and its receptor are expressed in the P2 and adult SVZ, we investigated whether exogenous IFN $\gamma$ could regulate the formation of primary neurospheres from freshly isolated cells grown in the presence of EGF and FGF. Our results revealed that IFN $\gamma$ treatment of P2 SVZ cells decreased neurosphere formation at all doses examined, with a reduction ranging from $50 \%$ at $1 \mathrm{ng} / \mathrm{ml}$ to $70 \%$ at $100 \mathrm{ng} / \mathrm{ml}$ (Fig. $2 \mathrm{~A}$ ). In addition, treatment of cells isolated from the SVZ of adult animals with $1 \mathrm{ng} / \mathrm{ml} \mathrm{IFN} \gamma$ caused a significant inhibition in neurosphere formation (Fig. $2 A)$. At $50 \mathrm{ng} / \mathrm{ml}$ IFN $\gamma$, there was an $\sim 50 \%$ decrease in neurosphere frequency (Fig. $2 A$ ), an effect that reached a plateau at 100 $\mathrm{ng} / \mathrm{ml}$. We also found that IFN $\gamma$ treatment resulted in a significant decrease in the size of neurospheres formed by the adult SVZ cells (Fig. 2 B). These results suggested that IFN $\gamma$ affects the pro- liferation rate of the precursor progeny, as well as the frequency of neurosphere formation.

To determine whether the reduction in neurosphere formation observed in response to IFN $\gamma$ was attributable to a reduction in proliferation rather than an increase in cell death, we used $\mathrm{Bax}^{-1-}$ mice, which have been reported to lack programmed cell death (Sun et al., 2004). When neurosphere formation from $B a x^{-/-}$and wild-type control SVZ cells cultured with or without $50 \mathrm{ng} / \mathrm{ml}$ IFN $\gamma$ were compared, we observed a similar reduction in primary neurosphere formation with IFN $\gamma$ treatment in both cases (Fig. 2C). Moreover, we also found that the total number of cells in the SVZ was equally decreased after IFN $\gamma$ treatment in the $\mathrm{Bax}^{-/-}$and wild-type mice (Fig. 2D), suggesting that the reduction of precursor activity by IFN $\gamma$ was not influenced by Bax deletion and was not attributable to precursor cell death.

\section{IFN $\gamma$ acts directly on a precursor population}

To test whether IFN $\gamma$ acts directly on a precursor population, we plated SVZ cells at limiting dilutions. The limiting dilution analysis revealed that the reduction in neurosphere numbers was consistent at all cell densities tested from both the control group and the IFN $\gamma$-treated group (Fig. $2 E$ ) (control, $r=0.97$; IFN $\gamma, r=$ 0.94 ), indicating that the inhibitory effect of IFN $\gamma$ was probably not attributable to paracrine factors released in response to IFN $\gamma$ treatment. To directly test this, we examined the effects of IFN $\gamma$ on the NPs at a single-cell level. Adult SVZ cells were plated at clonal density (one cell per well, which was confirmed by microscopic observation, as described in Materials and Methods) and cultured with or without $50 \mathrm{ng} / \mathrm{ml}$ IFN $\gamma$. Under these conditions, we found a $63 \%$ reduction in the frequency of primary neurosphere formation after IFN $\gamma$ treatment (Fig. $2 F$ ). To test whether this effect was also exerted on the precursors generated in neurospheres, we dissociated primary neurospheres and cultured the resultant cells at clonal density. In this case, IFN $\gamma$ induced an even stronger inhibitory effect, with $94 \%$ reduction in secondary neurosphere formation (Fig. $2 F$ ). These results indicate that IFN $\gamma$ acts directly on primary and passaged adult precursors at the single-cell level.

Because it has been shown previously that IFN $\gamma$ treatment can induce MHCI expression on NPs in the developing brain (Bailey et al., 1994; Yin et al., 2008), we predicted that the direct action of IFN $\gamma$ on NPs should result in the majority of the precursors expressing MHCI. To determine what proportion of NPs express MHCI at different developmental stages, cells from E12 brain and adult SVZ were treated with or without $10 \mathrm{ng} / \mathrm{ml} \mathrm{IFN} \gamma$ for $24 \mathrm{~h}$, this short-term treatment being insufficient to significantly affect the number of neurospheres generated in the presence of IFN $\gamma$ (data not shown). The MHCI-positive cells were then labeled using FITC-conjugated $\mathrm{H}-2 \mathrm{~K}^{\mathrm{b}}$ antibody and sorted into MHCIpositive or MHCI-negative fractions based on their fluorescence intensity. In the absence of IFN $\gamma, \mathrm{H}-2 \mathrm{k}^{\mathrm{b}}$-positive cells were rarely detected (Fig. 3A,C); after IFN $\gamma$ treatment, however, a significant proportion of cells expressed $\mathrm{H}-2 \mathrm{k}^{\mathrm{b}}$, the percentage becoming smaller with age (Fig. $3 B, D$ ).

After sorting, the neurosphere-forming cells were found to be predominantly in the $\mathrm{MHCI}$-positive population at both ages examined (Fig. 3E). The MHCI-positive precursors represented $98 \%$ of the total neurosphere-forming units at E12 and $68 \%$ in the adult. These findings further support the notion that the NPs are directly activated by IFN $\gamma$. 
Microglia modulate the inhibitory effect of IFN $\gamma$ on adult NPs

Given that it has been shown previously that microglia are also activated by IFN $\gamma$ (Streit et al., 1999), leading to the release of factors such as cytokines, which potentially exert an effect on NP activity (Nakanishi et al., 2007), we next investigated the effect of microglia on the proliferation of NPs in the presence or absence of IFN $\gamma$. To confirm that IFN $\gamma$ can activate microglia in the adult SVZ, we first assessed MHCI expression on these microglia using eGFP-cfms mice, in which the microglia have been shown previously to be labeled with eGFP (Sasmono et al., 2003). The results revealed that $84 \%$ of cells expressing a high level of eGFP were MHCI positive (Fig. $4 A$ ) $24 \mathrm{~h}$ after IFN $\gamma$ treatment, whereas in the control, this value was only $23 \%$. To determine whether microglia influence the effect of IFN $\gamma$ on NPs, we then removed the eGFP-positive cells from the SVZ population by cell sorting and assessed the neurosphere formation of the remaining eGFP-negative cell population compared with that of unsorted cells. Culturing the eGFP-negative cells in $\mathrm{E}+$ $\mathrm{F}$ medium containing IFN $\gamma$ resulted in a much greater decrease in neurosphere formation compared with that observed in unsorted cells (89 vs 54\%) (Fig. 4B). This result indicates that microglia may protect at least a subpopulation of adult neurosphere-forming cells from the inhibitory effects of IFN $\gamma$ and suggests that almost all NPs are regulated by IFN $\gamma$.

Endogenous IFN $\gamma$ expression regulates the number of neurosphere-forming cells found in the $\mathrm{P} 2$ and adult SVZ

To examine whether endogenous IFN $\gamma$ has a similar effect on postnatal and adult NP activity in vivo to that observed in vitro in the presence of exogenous IFN $\gamma$, we compared the frequency of neurospheres formed from $I F N \gamma^{-/-}$and IFN $\gamma^{+/+}$mice. This revealed that the number of neurospheres formed from P2 IFN ${ }^{-1-}$ SVZ cells was threefold higher than that from $I F N \gamma^{+/+}$cells when cultured in $\mathrm{E}+\mathrm{F}$ alone (Fig. $5 A$ ). The $I F N \gamma^{-1-}$ neurospheres were also significantly larger than the IFN $\gamma^{+/+}$neurospheres (IFN $\gamma^{-/-}, 143 \pm 4 \mu \mathrm{m}$ in diameter, $n=74$ neurospheres; IFN $\gamma^{+/+}, 112 \pm 4 \mu \mathrm{m}, n=78$ neurospheres; $\left.p<0.001\right)$. Similarly, we found that SVZ cells from adult IFN $\gamma^{-1-}$ mice exhibited a more than twofold increase in neurosphere frequency compared with those from adult $I F N \gamma^{+/+}$mice when cultured in $\mathrm{E}+\mathrm{F}$ alone (Fig. $5 B$ ). The IFN $\gamma^{-/-}$neurospheres were also significantly larger than the IFN $\gamma^{+/+}$neurospheres $\left(\right.$IFN $\gamma^{-/-}, 173 \pm 4 \mu \mathrm{m}, n=66$ neurospheres; IFN $\gamma^{+/+}, 140 \pm 3 \mu \mathrm{m}, n=64$ neurospheres; $p<0.001$ ).

As expected, both $I F N \gamma^{-1-}$ and IFN $\gamma^{+/+}$cells from P2 and adult mice were sensitive to exogenous IFN $\gamma$. When grown in the presence $0.05,{ }^{* * *} p<0.001$.

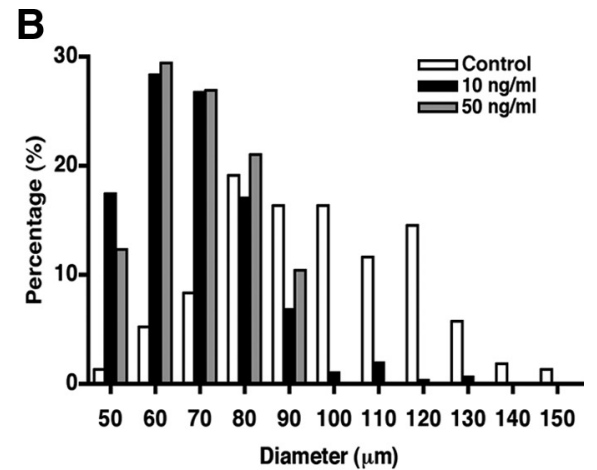

D

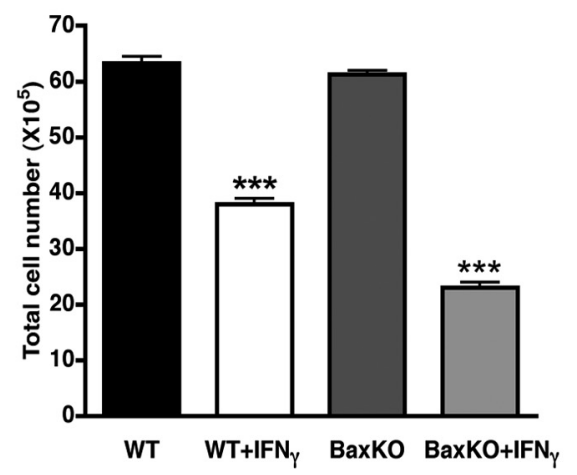

$\mathbf{F}$

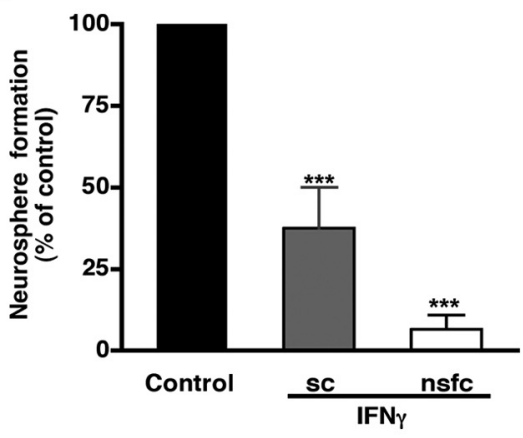

Figure 2. Effects of IFN $\gamma$ on the activity of P2 and adult NPs. $\boldsymbol{A}$, Inhibitory effects of IFN $\gamma$ on P2 and adult SVZ cells at different doses. $\boldsymbol{B}$, Size distribution of primary neurospheres formed from adult SVZ cells. IFN $\gamma$-treated SVZ cells generated smaller primary neurospheres than those cultured without IFN $\gamma$. C, A similar decrease in neurosphere formation was observed after IFN $\gamma$-treatment of Bax knock-out (BaxKO) and wild-type (WT) mice. D, Cell viability in the SVZ from Bax or without $50 \mathrm{ng} / \mathrm{ml} \mathrm{IFN} \gamma$. Cells were plated at densities ranging from 1 to 640 cells per well. The reduction in neurosphere numbers was consistent at all cell densities tested from both the control group and the IFN $\gamma$-treated group. $\boldsymbol{F}$, Inhibitory on primary and secondary neurosphere formation using a clonal assay. IFN $\gamma$ treatment induced 63 and $94 \%$ reduction in neurosphere formation from the primary adult SVZ cells and neurosphere-forming cells compared with the control, respectively. Data were normalized to percentage of control. sc, SVZ cells; nsfc, neurosphere-forming cells. ${ }^{*} p<$

of exogenous IFN $\gamma$, the number of $I F N \gamma^{-/-}$and $I F N \gamma^{+/+}$neurospheres decreased by 5.6-fold and 4.7-fold, respectively (Fig. $5 A, B)$, and the neurospheres were significantly smaller (P2: IFN $\gamma^{-/-}, 143 \pm 4 \mu \mathrm{m}, n=74$ neurospheres vs $83 \pm 2 \mu \mathrm{m}, n=$ 91 neurospheres; IFN $\gamma^{+/+}, 112 \pm 4 \mu \mathrm{m}, n=78$ neurospheres vs $78 \pm 2 \mu \mathrm{m}, n=20$ neurospheres; $p<0.001$ in both cases; adult: IFN $\gamma^{-1-}, 173 \pm 4 \mu \mathrm{m}, n=66$ neurospheres vs $119 \pm 3 \mu \mathrm{m}, n=$ 55 neurospheres; IFN $\gamma^{+/+}, 140 \pm 3 \mu \mathrm{m}, n=64$ neurospheres vs $105 \pm 3 \mu \mathrm{m}, n=68$ neurospheres; $p<0.001$ in both cases). Overall, these results are consistent with endogenous IFN $\gamma$ in the SVZ exerting an inhibitory effect in situ. 


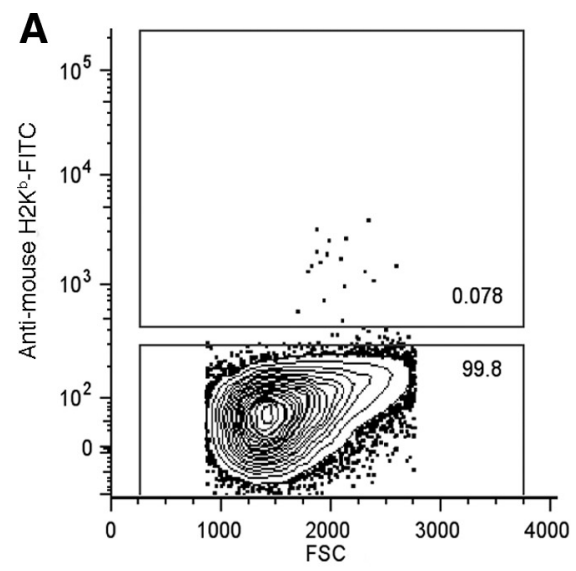

C
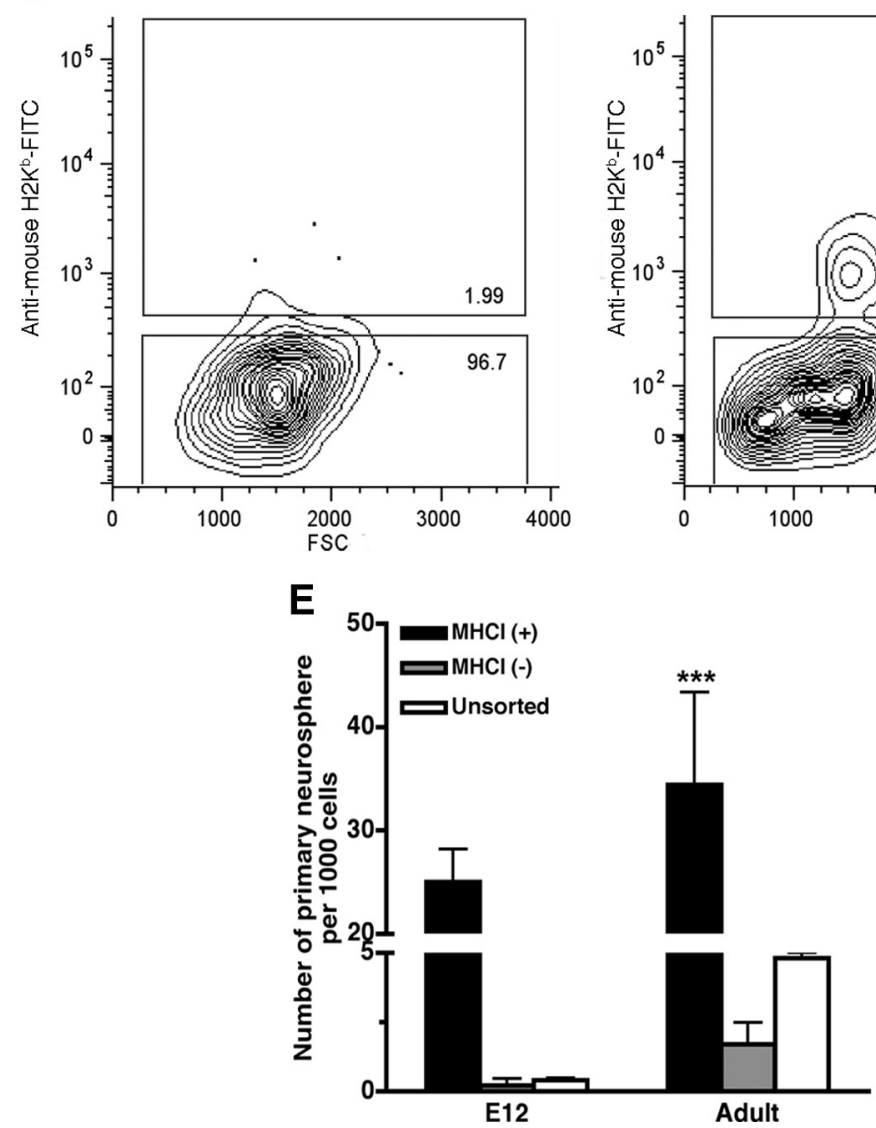

Figure 3. Flow cytometric analysis of $\mathrm{MHCl}$ expression on cells from E12 brain and adult SVZ incubated in the absence $(\boldsymbol{A}, \boldsymbol{C})$ or presence $(\boldsymbol{B}, \boldsymbol{D})$ of $10 \mathrm{ng} / \mathrm{ml}$ IFN $\gamma$ for $24 \mathrm{~h}$. The cells were immunostained with an FITC-conjugated mouse anti-mouse $\mathrm{H}-2 \mathrm{~K}^{\mathrm{b}}$ monoclonal antibody. The horizontal axis is forward light scatter (FSC), which is proportional to cell size. The vertical axis is in arbitrary units of immunoreactive fluorescence. Cells were separated into two populations (MHCl-positive and MHCl-negative) on the basis of $\mathrm{H}-2 \mathrm{~K}^{\mathrm{b}}$-FITC immunoreactivity, and gates were selected to exclude cell debris, clumps of cells, and dead cells. Thirty thousand events were selected in each set of experiments. MHCl expression was rarely detected on cells from E12 brain $(\boldsymbol{A})$ or adult SVZ ( () in the absence of IFN $\gamma$. There was significant upregulation of MHCl expression on cells from E12 brain $(\boldsymbol{B})$ and adult SVZ (D) after treatment with IFN $\gamma$.E, Precursor activity of $\mathrm{MHCl}$-positive and $\mathrm{MHCl}$-negative cells at E12 and in the adult. The frequency of neurosphere formation was significantly greater from MHCl-positive cells than from $\mathrm{MHCl}$-negative cells at all ages. ${ }^{* *} p<0.001$.

ary neurospheres. We found a more than twofold increase in the frequency of secondary neurospheres derived from cells isolated from $\mathrm{IFN \gamma}^{-/-}$primary neurospheres compared with cells isolated from $\mathrm{IFN}^{+/+}$neurospheres (Fig. 5C). Although the frequency of secondary neurospheres gives some indication of the increased self-renewal of cells isolated from the $I F N \gamma^{-/-}$mice, it is only longterm passaging that addresses the question of extensive self-renewal capacity. In this respect, we found that the number of $I F N \gamma^{-I-}$ neurospheres increased exponentially with passaging, supporting the idea that the increased frequency observed at the secondary passage was sustained over this period. In contrast, the number of their $\mathrm{IFN}^{+/+}$counterparts began to plateau after two passages (Fig. $5 D)$. Strikingly, in the presence of 50 $\mathrm{ng} / \mathrm{ml}$ IFN $\gamma$, both $I F N \gamma^{-/-}$and IFN $\gamma^{+/+}$ neurospheres could only be passaged one or two times (Fig. 5D), and the number of secondary neurospheres formed by both IFN $\gamma^{-/-}$and IFN $\gamma^{+/+}$cells was reduced by $>90 \%$ (Fig. $5 C$ ), far greater than the decrease observed for primary neurospheres (Fig. 5B), again indicating the ability of IFN $\gamma$ to actively inhibit NP activity.

In addition to increased self-renewal capacity, the size of the IFN $\gamma^{-/-}$neurospheres was much larger than that of the IFN $\gamma^{+/+}$neurospheres at each passage. For example, at passage 6 , the average of diameter was $160 \pm 12 \mu \mathrm{m}$ for $I_{F N}{ }^{-/-}$ neurospheres ( $n=80$ neurospheres) (Fig. $5 E)$ and $89 \pm 2 \mu \mathrm{m}$ for $\mathrm{IFN}^{+/+}$neurospheres $(n=85$ neurospheres; $p<$ 0.0001) (Fig. 5F).

\section{Adult IFN $\gamma^{-/-}$mice have increased numbers of proliferating cells in the SVZ}

Having shown that IFN $\gamma$ negatively regulates the number of precursors in the adult SVZ, we next examined whether this was reflected by an increased number of mitotically active cells in the IFN $\gamma^{-1-}$ mice. Both $I F N \gamma^{+/+}$and $I F N \gamma^{-/-}$mice were given one intraperitoneal injection of BrdU $1 \mathrm{~h}$ before they were killed, and the resultant labeling was analyzed. The results revealed a significantly increased number of BrdU-positive cells along the

Adult IFN $\gamma^{-/-}$mice have increased self-renewal of precursor cells in the SVZ

One of the key criteria for defining stem cells is their ability to self-renew over an extended period of time. We first investigated the effects of endogenous IFN $\gamma$ on the self-renewal ability of precursors from the adult $I F N \gamma^{-/-}$and $\mathrm{IFN}^{+/+}$SVZ by determining the capacity of primary neurospheres to produce second- lateral wall of the lateral ventricles at all levels of the $I F N \gamma^{-/-} \mathrm{SVZ}$ analyzed (Fig. 6A, B,E) compared with the number observed in the IFN $\gamma^{+/+}$SVZ (Fig. 6C-E). We also tested intraventricular infusion of IFN $\gamma$ but found that inflammatory infiltrates into the parenchyma were evident on the infused side of the IFN $\gamma$-treated mice compared with controls (data not shown). Unfortunately, this infiltration, which was primarily located in the area adjacent 
to the SVZ and the striatum, made it impossible to determine the direct effect of IFN $\gamma$ on the precursors.

\section{IFN $\gamma$ regulates differentiation}

To determine whether IFN $\gamma$ influences the differentiation potential of NPs, primary neurospheres derived from the SVZ of $\mathrm{IFN}^{-/-}$and $\mathrm{IFN}^{+/+}$mice were assayed in vitro for their capacity to form neurons, astrocytes, and oligodendrocytes. For comparative analysis of differentiation potential, undissociated primary neurospheres of equal diameter were selected from $I F N \gamma^{+/+}, I F N \gamma^{-/-}$, and IFN $\gamma$-treated SVZ cultures. Although all neurospheres contained cells expressing the neuronal marker $\beta$ III-tubulin, the percentage of $\beta$ IIItubulin-positive neurons in the $I F N \gamma^{+/+}$ neurospheres (Fig. $7 A, J, M$ ) was much lower than that in $I F N \gamma^{-1-}$ neurospheres

(Fig. $7 B, K, M)$. Consistent with this finding, we found that treatment with $50 \mathrm{ng} / \mathrm{ml}$ IFN $\gamma$ (Fig. 7C, $L, N$ ) significantly reduced neuronal production compared with that in untreated cultures (Fig. $7 A, J, M)$.

In addition to IFN $\gamma$ regulating neuronal number, we found a significant decrease in the number of $\mathrm{O} 4$-positive oligodendrocytes in the IFN $\gamma^{+/+}$neurospheres (Fig. 7D, J,M) compared with the $I F N \gamma^{-1-}$ neurospheres (Fig. 7E,K,M), and IFN $\gamma$ treatment significantly reduced the number of O4-positive cells in differentiated neurospheres (Fig. $7 F, L, N$ ). The percentage of IFN ${ }^{+/+}$neurospheres containing O4-positive cells was also significantly lower than that of $\mathrm{IFN \gamma}^{-1-}$ neurospheres $\left(I F N \gamma^{+/+}, 42 \%, n=69\right.$ neurospheres; IFN ${ }^{-/-}, 94 \%, n=57$ neurospheres; $p<0.001)$. Moreover, almost no neurospheres $(<1 \%)$ treated with IFN $\gamma$ contained O4-positive cells compared with $19 \%$ of size-matched control neurospheres. Overall, these results revealed that differentiation of neurons and oligodendrocytes was markedly increased from the SVZ cells lacking endogenous IFN $\gamma$.

Quantitative analysis of cells expressing the astrocytic cell marker GFAP revealed a corresponding significant increase in the percentage of GFAP-positive cells in the IFN $\gamma^{+/+}$neurospheres (Fig. 7G,J,M) compared with the $I F N \gamma^{-1-}$ neurospheres (Fig. $7 H, K, M)$. Similarly, the percentage of GFAP-positive cells in IFN $\gamma$-treated neurospheres (Fig. $7 I, L, N)$ was significantly greater than that in nontreated neurospheres (Fig. $7 G, J, M$ ), indicating that, in the absence of endogenous IFN $\gamma$, differentiation toward an astrocytic fate was reduced.

\section{Increased proportion of newborn neurons in the adult IFN $\boldsymbol{\gamma}^{-/-}$olfactory bulb}

It is known that the proliferating cells in the SVZ migrate via the rostral migratory stream to the olfactory bulb in which they differentiate to provide new cells, mainly in the granular and periglomerular layers. To investigate whether IFN $\gamma^{-1-}$ mice have alterations in the fate of newborn cells in the olfactory bulb, we gave adult $I F N \gamma^{-1-}$ and wild-type mice five pulses of BrdU and examined the number of newborn neurons 4 weeks after the injection. This analysis revealed that most of the BrdU-positive cells were scattered throughout the GCL in both genotypes and that the majority of newborn cells in the GCL were NeuNpositive neurons. Furthermore, the proportion of NeuN-positive neurons in the BrdU-positive cell population in the GCL was significantly higher in the IFN $\gamma^{-/-}$olfactory bulb than in the IFN $\gamma^{+/+}$olfactory bulb $\left(\right.$IFN $\gamma^{+/+}, 66 \pm 3.2 \%, n=499$ cells; IFN $\gamma^{-1-}, 87 \pm 2.4 \%, n=760$ cells; $\left.p<0.001\right)$, similar to the result observed in the differentiated $I F N \gamma^{-1-}$ neurospheres. Moreover, the total number of cells from the dissociated adult $I F N \gamma^{-/-}$olfactory bulb was twofold greater than that from wildtype counterparts $\left(\right.$ IFN $\gamma^{+/+}, 9.4 \pm 1.1 \times 10^{4}$ cells vs IFN $\gamma^{-/-}$, $18.9 \pm 1.7 \times 10^{4}$ cells; $n=8$ olfactory bulbs in both cases; $p<$ 0.001 ), and the total number of GCL cells was also much greater than that in wild-type controls when counts were performed on sections from the median level of the IFN $\gamma^{+/+}$and $I F N \gamma^{-/-}$olfactory bulbs $\left(I F N \gamma^{-/-}, 26,300 \pm 885\right.$ cells/olfactory bulb vs IFN $\gamma^{+/+}, 17,700 \pm 428$ cells/olfactory bulb; $n=3$ olfactory bulbs in both cases; $p<0.01)$. No significant difference was found in the total number of periglomerular layer cells per glomerulus between mutant and wild-type olfactory bulbs $\left(I F N \gamma^{+/+}, 48 \pm 5\right.$ cells, $n=111$ glomeruli; IFN $\gamma^{-/-}, 44 \pm 1$ cells, $n=99$ glomeruli; NS). These results suggest that the increase in cells in the IFN $\gamma^{-1-}$ olfactory bulb mainly derives from the GCL layer. Surprisingly, we did not find a significant increase in either the size $\left(I F N \gamma^{+/+}\right.$, $4.0 \pm 0.01 \mathrm{~mm}, n=13$ olfactory bulbs; $I F N \gamma^{-1-}, 3.9 \pm 0.02 \mathrm{~mm}$, $n=12$ olfactory bulbs; NS) or the weight $\left(I F N \gamma^{+/+}, 10.5 \pm 0.3\right.$ $\mathrm{mg}$ vs $I F N \gamma^{-/-}, 10.9 \pm 0.3 \mathrm{mg} ; n=8$ olfactory bulbs in both cases; NS) of the olfactory bulb. Furthermore, no significant difference was found in the number of neurospheres cultured from mutant and wild-type olfactory bulbs $\left(\right.$ IFN $^{+/+}, 180 \pm 82$ neurospheres, $n=7$ olfactory bulbs; IFN $\gamma^{-/-}, 328 \pm 47$ neurospheres; $n=8$ olfactory bulbs; NS).

Finally, we saw no differences in either cytoarchitecture or the neuroblast-glial arrangement of the rostral migratory stream between wild-type and mutant mice (data not shown). Moreover, $3 \mathrm{~d}$ after BrdU injections, there were no significant changes in the number of BrdU-positive cells between wild-type and mutant mice $\left(\mathrm{IFN}^{+/+}, 114 \pm 19\right.$ cells per section vs $I F N \gamma^{-/-}, 110 \pm$ 10.4 cells per section; $n=3$ olfactory bulbs in both cases). These results indicate that IFN $\gamma$ deficiency does not affect the tangential migration of proliferating cells.

\section{IFN $\gamma$ stimulates NP activity at E12}

Given that IFN $\gamma$ actively regulates precursor activity in postnatal and adult brains, we next examined whether exogenous IFN $\gamma$ also 

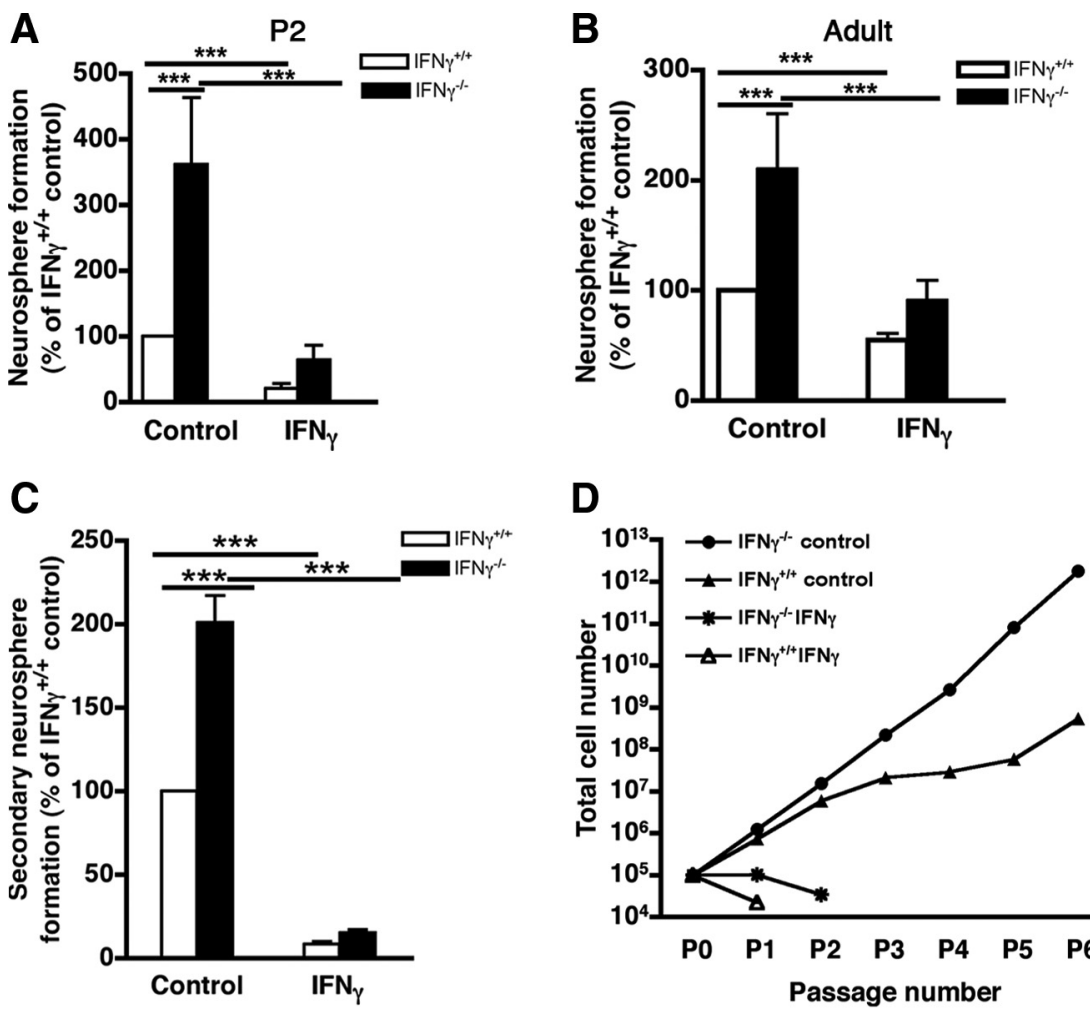

D

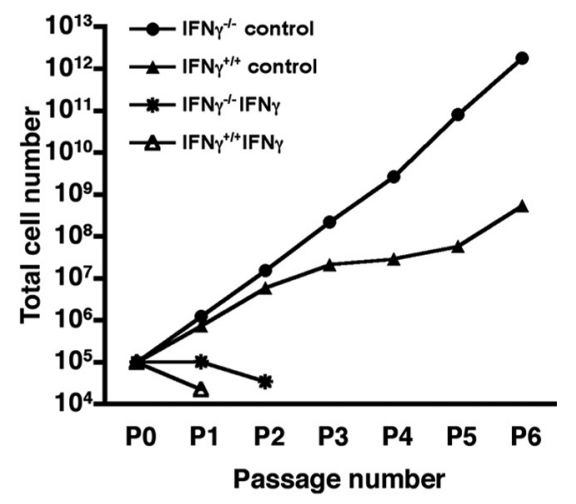

E

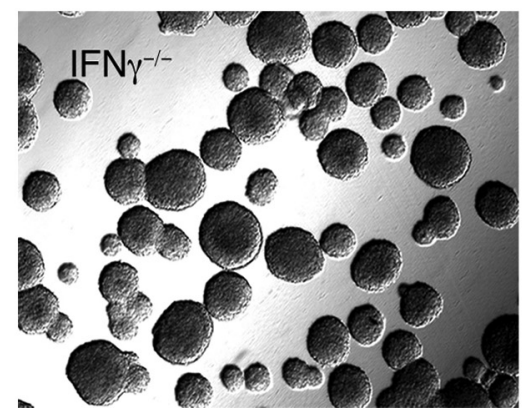

$\mathbf{F}$

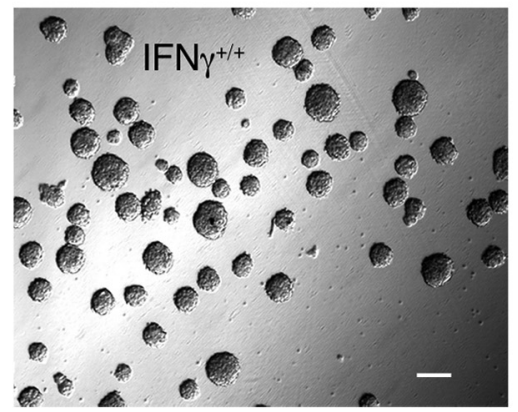

Figure 5. IFN $\gamma$ deletion influences the growth capacity of NPs from P2 and adult SVZ cells. At P2 and in the adult, the number of primary IFN $\gamma^{-/-}$neurospheres was significantly greater than the number of $I F N \gamma^{+/+}$neurospheres. In the presence of exogenous IFN $\gamma$, the number of primary IFN $\gamma^{-/-}$and IFN $\gamma^{+/+}$neurospheres dramatically decreased at $\mathrm{P} 2(\boldsymbol{A})$ and in the adult $(\boldsymbol{B}) . n=5$ animals in both cases. $\boldsymbol{C}$, Secondary neurosphere formation revealed that cells dissociated from primary adult IFN $\gamma^{-/-}$neurospheres had greater proliferative capacity than those from IFN $\gamma^{+/+}$neurospheres. D, Long-term passaging of adult IFN $\gamma^{+/+}$and IFN $\gamma^{-/-}$neurospheres revealed that adult IFN $\gamma^{-/-}$NPs have a higher self-renewal capacity than IFN $\gamma^{+/+}$NPs in the presence of $\mathrm{E}+\mathrm{F}$ alone. Neither adult IFN $\gamma^{+/+}$nor IFN $\gamma^{-/-} \mathrm{NPs}$ could be continuously passaged in the presence of $50 \mathrm{ng} / \mathrm{ml} \mathrm{IFN} \gamma$. Representative images showing that adult IFN $\gamma^{-/-} \mathrm{NPs}(\boldsymbol{E})$ generated larger neurospheres than IFN $\gamma^{+/+}$precursors $(\boldsymbol{F})$ at passage 6 in the presence of $\mathrm{E}+\mathrm{F}$. Scale bar (in $\boldsymbol{F}$ ): $\boldsymbol{E}, \boldsymbol{F}, 100 \mu \mathrm{m}$. ${ }^{* * *} p<0.001$.

had an effect on E12 precursors. Although IFN $\gamma$ was undetectable in E12 brains, IFN $\gamma$ receptor mRNA was expressed. When we treated cells freshly isolated from E12 brains with or without IFN $\gamma$, we found that, in contrast to the inhibitory effect of IFN $\gamma$ at $\mathrm{P} 2$ and in the adult, treatment of E12 neural cells with even $1 \mathrm{ng} / \mathrm{ml}$ IFN $\gamma$ induced a significant increase in neurosphere formation compared with control cultures grown in $\mathrm{E}+\mathrm{F}$ medium alone, and $50 \mathrm{ng} / \mathrm{ml} \mathrm{IFN \gamma}$ induced a greater than twofold increase in the frequency of neurospheres (Fig. 8A). However, no significant difference was found in the size distribution of primary neurospheres generated from E12 cells treated with or without IFN $\gamma$ (data not shown). Moreover, the lack of expression of IFN $\gamma$ at E12 suggests no effect of endogenous IFN $\gamma$ on NP activity. We also examined the frequency of neuro- sphere formation of cells isolated from $I F N \gamma^{-1-}$ embryos and found no significant difference in the frequency of primary neurosphere formation between cells isolated from $I F N \gamma^{-1-}$ and $I F N \gamma^{+/+}$mice $\left(\mathrm{IFN} \gamma^{-/-}, 118 \pm 15 \%\right.$ of $\mathrm{IFN}^{+/+}$control).

Given our finding that exogenous IFN $\gamma$ treatment induced an increase in neurosphere number from the embryonic brain, we investigated a possible mechanism to explain this result. Previously, it has been shown that IFN $\gamma$ triggers ectopic expression of the Shh gene in cerebral granular cells during development (Wang et al., 2004) and that Shh signaling is required for the maintenance of neural stem cells during late development and in the adult CNS (Wallace, 1999; Wechsler-Reya and Scott, 1999; Lai et al., 2003; Palma et al., 2005; Han et al., 2008). We therefore investigated whether the IFN $\gamma$-induced increase in neurosphere formation at E12 was mediated by Shh using a selective inhibitor, cyclopamine (Cooper et al., 1998). Treatment of E12 cells with $5 \mu \mathrm{M}$ cyclopamine resulted in a significant decrease in neurosphere frequency, even in the absence of IFN $\gamma$ (Fig. $8 B$ ), suggesting that the E12 NPs require endogenous Shh signaling for their normal proliferation in $\mathrm{E}+\mathrm{F}$ medium. Treating cells with Shh in the absence of IFN $\gamma$ produced an increase in the frequency of primary neurospheres similar to that seen with IFN $\gamma$ (Fig. $8 B$ ). However, combining IFN $\gamma$ and Shh produced no additional increase in neurosphere number, suggesting that they act on the same population of NPs. More importantly, cyclopamine had a profound effect on the frequency of IFN $\gamma$-stimulated neurospheres, causing a decrease back to control levels (Fig. $8 B$ ). Thus, these results suggest that IFN $\gamma$ requires Shh for its stimulatory effect on E12 precursors.

\section{Discussion}

The major finding of this study is that IFN $\gamma$ acts as a potent negative regulator of NP activity in the non-inflammatory adult SVZ, with exogenous IFN $\gamma$ strongly inhibiting neurosphere formation. More importantly, in the absence of endogenous IFN $\gamma$, the number and average size of the SVZ-derived neurospheres increases. We also provide evidence that endogenous IFN $\gamma$ directly regulates at least a subpopulation of stem cells, with IFN $\gamma$ deficiency resulting in more secondary neurospheres with greater self-renewal and multipotentiality. These in vitro results were confirmed by the in vivo observation that IFN $\gamma$ deficiency leads to a rise in the number of mitotic BrdU-positive cells in the SVZ and an increased percentage of newly born neurons in the olfactory bulb. Furthermore, NPs isolated from $I F N \gamma^{-/-}$mice exhibit an increased self-renewal ability and produce more differentiated neurons and oligodendrocytes. 

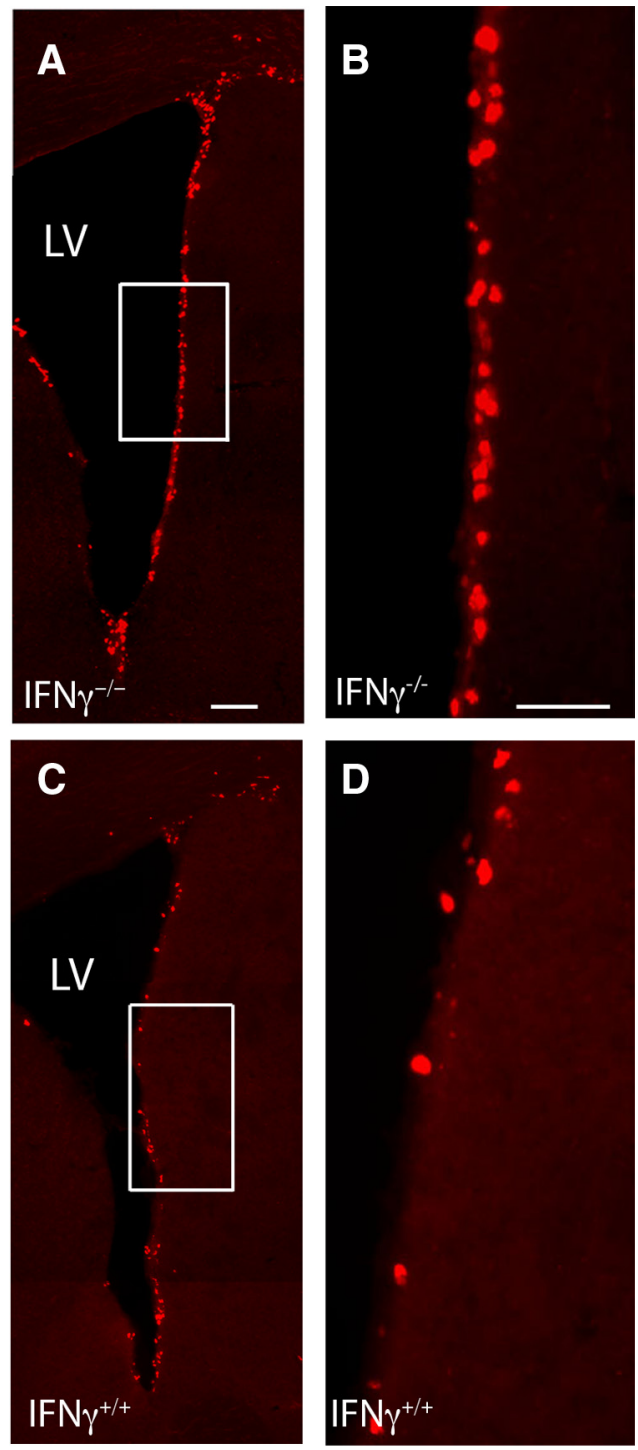

E

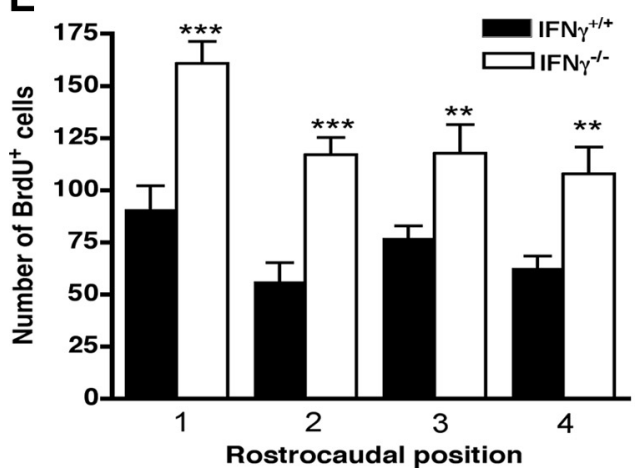

Figure 6. Increased number of BrdU-positive cells in the SVZ of the lateral wall of the lateral ventricle of IFN $\gamma^{-/-}$and IFN $\gamma^{+/+}$mice $1 \mathrm{~h}$ after a single BrdU injection. $A$, A representative lowpower image of BrdU-positive cells in the SVZ of the IFN $\gamma^{-1-}$ brain. $\boldsymbol{B}$, Higher-power image of the boxed region in $\boldsymbol{A}$. $\boldsymbol{C}$, A representative low-power image of BrdU-positive cells in the SVZ of the IFN $\gamma^{+/+}$brain. D, Higher-power image of the boxed region in C. An increase in BrdU-positive cells was found in the lateral wall of the lateral ventricle in the IFN $\gamma^{-1-}$ mice. $E$, Quantification of BrdUpositive cells in the SVZ from both IFN $\gamma^{-/-}$and IFN $\gamma^{+/+}$animals. BrdU-positive SVZ cells were counted in sections taken at four evenly spaced rostrocaudal intervals at $0.26,0.50,0.74$, and $0.98 \mathrm{~mm}$ relative to bregma. The data were expressed as an absolute number of BrdU-positive cells per level. The results revealed a significant increase in the number of BrdU-positive cells in the mutant mice from the four selected frontal brain sections. LV, Lateral ventricle. ${ }^{* *} p<0.01,{ }^{* * *} p<0.001$. Scale bars: $A$, C, $200 \mu \mathrm{m} ; \boldsymbol{B}, \boldsymbol{D}, 200 \mu \mathrm{m}$.
The above findings provide the first evidence that endogenous IFN $\gamma$ exerts a regulatory effect in the stem cell niche in vivo and that this effect is a direct one, because the same results were obtained at the single-cell level. Furthermore, nearly all the neurospheres were derived from cells positive for MHCI, a downstream marker of IFN $\gamma$-mediated activation. Although T cells are the main source of IFN $\gamma$ throughout the body, these cells are relatively restricted from entering the healthy brain. However, it has been shown that low IFN $\gamma$ levels can be produced by nonimmune or non-inflammatory cells, such as astrocytes, fibroblasts, and cerebrovascular endothelial cells (Rady et al., 1995; De Simone et al., 1998; Wei et al., 2000), which comprise the resident cells of the SVZ. Our PCR analysis (data not shown) reveals that IFN $\gamma$ is present in both primary SVZ tissue and untreated neurosphere cultures. Therefore, in the normal brain, these SVZderived non-inflammatory cells could provide a source of IFN $\gamma$ by acting directly on NPs. This also explains why $\mathrm{IFN \gamma}^{-1-}$ precursors continue to proliferate better than their wild-type counterparts over serial passages. The question that then arises is how IFN $\gamma$ negatively regulates NP proliferation. One possibility is that IFN $\gamma$ induces cell-cycle arrest, an action that has been demonstrated previously in carcinoma cells (Burke et al., 1997; Shyu et al., 2000; Vivo et al., 2001; Baka et al., 2009) and mammalian epithelial cells (Harvat and Jetten, 1996). The anti-proliferative action in these cells is mainly regulated via activation of signal transducer and activator of transcription 1 (STAT1) and downregulation of cyclin A and cyclin E expression (Kortylewski et al., 2004). A similar inhibitory mechanism may also exist for NPs, with a recent study reporting that IFN $\gamma$-induced NP growth arrest occurs in the $\mathrm{G}_{1}$ phase of the cell cycle, being mediated via the STAT1-dependent signaling pathway (Lum et al., 2009). IFN $\gamma$ mediated inhibition of cell-cycle progression could also occur via upregulation of the cyclin-dependent kinase inhibitor p27 (Lum et al., 2009), a possibility supported by the finding that overexpression of p27 reduces the proliferation and self-renewal of SVZ cells (Li et al., 2009). However, because it has also been reported that IFN $\gamma$ may partially regulate cell-cycle arrest via a STAT1independent IFN $\gamma$-signaling pathway (Gough et al., 2008), such as acting through $\mathrm{pRb}$ or c-Myc in macrophages (Ramana et al., 2002) or CrKL in hematopoietic progenitors (Platanias et al., 1999), this remains a possibility.

The present study also provides evidence that IFN $\gamma$ plays an important role in regulating the differentiation of NPs in the adult SVZ. Our results reveal that IFN $\gamma$ deficiency leads to increased neuronal production in vitro, with IFN $\gamma$ treatment of wild-type cells producing the opposite effect. In contrast, IFN $\gamma$ has been reported previously to promote neuronal differentiation of NPs (Wong et al., 2004; Kim et al., 2007; Leipzig et al., 2010), possibly as a result of different assay conditions (e.g., Wong et al. exposed dissociated neurosphere cells to IFN $\gamma$ throughout differentiation, whereas in our paradigm, the treated NPs differentiated in IFN $\gamma$-free medium). Importantly, our in vitro findings were strongly supported by the observation that IFN $\gamma$ deficiency results in an increased number of newborn neurons in the olfactory bulb, providing the first evidence that endogenous IFN $\gamma$ controls neuronal production. Our results also reveal that IFN $\gamma$ deficiency leads to more proliferative BrdUpositive cells in the SVZ, which are reported to correspond to neuroblasts and transit-amplifying cells (Doetsch et al., 1997), which then migrate via the rostral migratory stream to the olfactory bulb. It is therefore reasonable to speculate that the increase in newborn neurons observed in the mutant olfactory bulb is caused by an increase in the number of neuroblasts generated in 

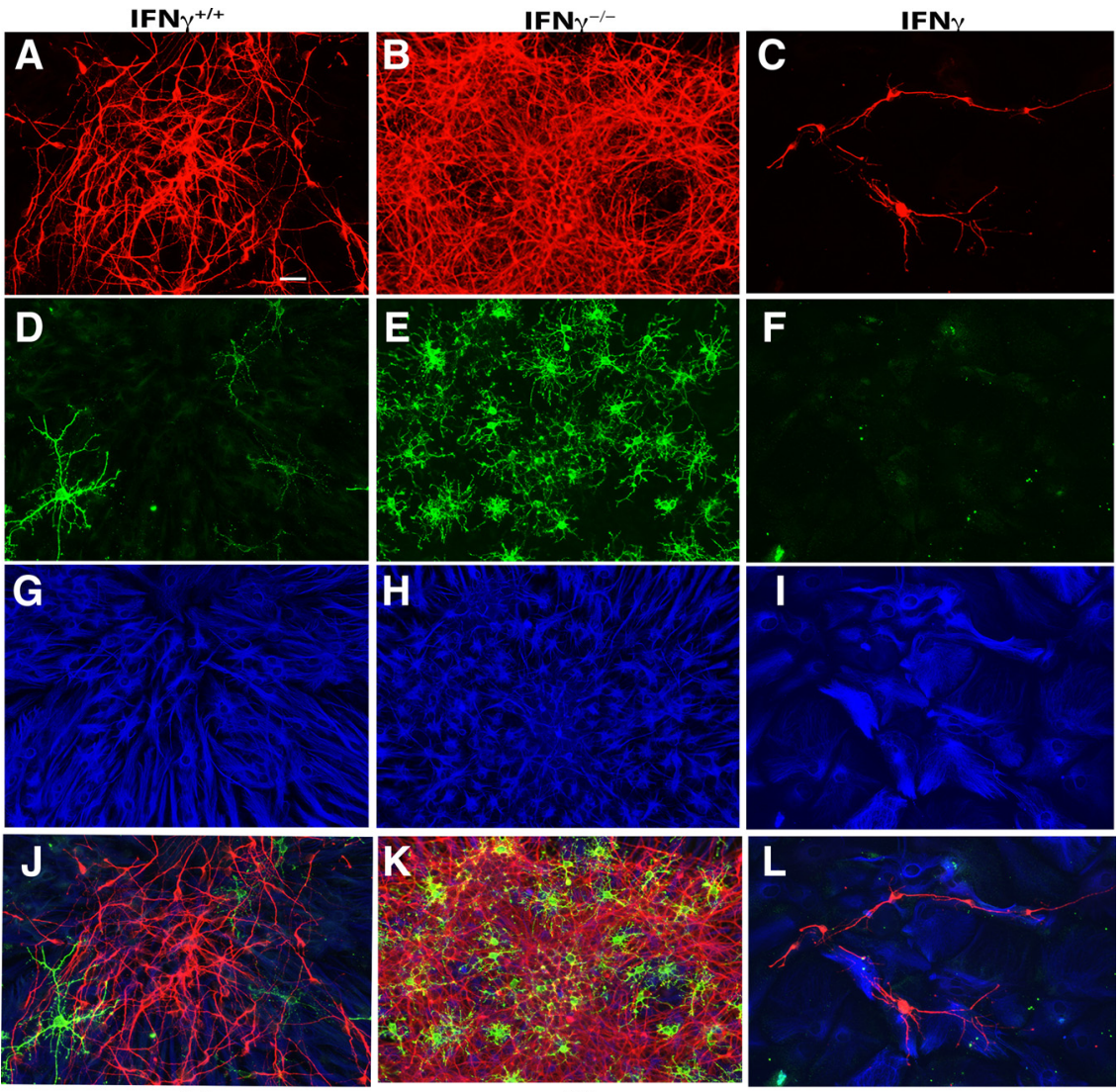

M
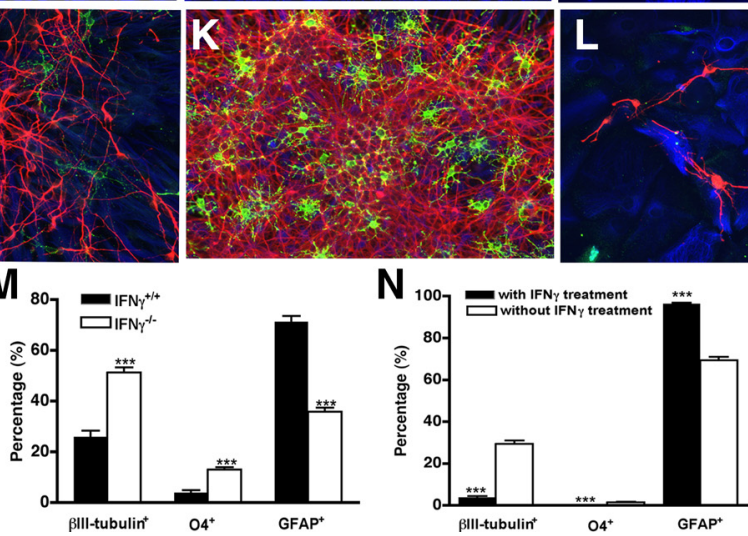

Figure 7. IFN $\gamma$ regulates the generation of neurons, oligodendrocytes, and astrocytes. Size-matched undissociated IFN $\gamma^{+/+}$ IFN ${ }^{-/-}$, and IFN $\gamma$-treated neurospheres were differentiated and stained for the neuronal marker $\beta I I I-t u b u l i n($ red), the oligodendrocyte marker 04 (green), and the astrocytic marker GFAP (blue). $A-I$, Representative images of individual IFN $\gamma^{+/+}(\boldsymbol{A}, \mathbf{D}$ $\boldsymbol{G})$, IFN $\gamma^{-/-}(\boldsymbol{B}, \boldsymbol{E}, \boldsymbol{H})$, and IFN $\boldsymbol{\gamma}$-treated $(\boldsymbol{C}, \boldsymbol{F}, \boldsymbol{I})$ neurospheres stained for $\beta$ III-tubulin, 04, and GFAP. J, A merged image of $\boldsymbol{A}, \boldsymbol{D}$ and $\boldsymbol{G} . \boldsymbol{K}$, A merged image of $\boldsymbol{B}, \boldsymbol{E}$, and $\boldsymbol{H} . \boldsymbol{L}, \mathbf{A}$ merged image of $\boldsymbol{C}, \boldsymbol{F}$, and $\boldsymbol{I} . \boldsymbol{M}$, Quantification of the production of neurons, oligodendrocytes, and astrocytes in primary IFN $\gamma^{+/+}$and $I F N \gamma^{-/-}$neurospheres. More neurons and oligodendrocytes but fewer astrocytes were generated from IFN $\gamma^{-/-}$neurospheres than from IFN $\gamma^{+/+}$neurospheres. N, Quantification of the production of neurons, oligodendrocytes, and astrocytes in primary neurospheres with or without IFN $\gamma$ treatment. IFN $\gamma$ treatment significantly reduced the production of neurons and oligodendrocytes but increased the generation of astrocytes. Scale bar (in $\boldsymbol{A}$ ): $\boldsymbol{A}-\boldsymbol{L}, 100 \mu \mathrm{m} .{ }^{* * *} p<0.001$.
A

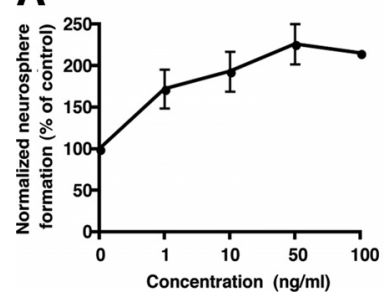

B

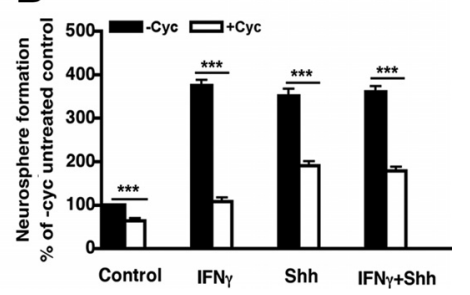

Figure 8. Effects of IFN $\gamma$ on $\mathrm{E} 12$ neurosphere formation. $\boldsymbol{A}$, IFN $\gamma$ increased primary neurosphere formation from E12 brain cells at all doses tested. $\boldsymbol{B}$, Effects of the Shh inhibitor cyclopamine on IFN $\gamma$ - and/or Shh-treated neurospheres generated from E12 neural cells. IFN $\gamma$ or Shh increased E12 neurosphere formation. After the addition of cyclopamine, neurosphere formation was significantly inhibited, indicating that Shh is required for the IFN $\gamma$-induced increase in proliferation of NPs at E12. Cyc, Cyclopamine. ${ }^{* * *} p<0.001$. the SVZ. This increase is unlikely to be attributable to a change in neuroblast migration, because we saw no evidence of any such effect and the neuroblast-glial arrangement was similar in the rostral migratory stream of mutant and wild-type mice. We also exclude the possibility of an increase in local NPs in the olfactory bulb contributing to the neuronal increase, given that our results revealed a similar number of neurospheres in the olfactory bulbs of $I F N \gamma^{-1-}$ and wild-type mice. The production of olfactory interneurons continues postnatally as migratory neuroblasts differentiate into granule cells and periglomerular interneurons (Luskin, 1993). Additional histological examination of the IFN ${ }^{-/-}$olfactory bulb revealed an increased number of cells in the granule cell layer, whereas the periglomerular layer remained unaffected. Because it has been shown that neurogenesis correlates with olfactory ability (Magavi et al., 2005; Mouret et al., 2009), it is possible that IFN $\gamma$ plays some role in this sensory process.

As well as negatively regulating neural production, our findings demonstrate that endogenous IFN $\gamma$ also negatively influences NP commitment to the oligodendrocytic lineage, consistent with the results of a previous study using primary neonatal rat brain cultures (Agresti et al., 1996). Furthermore, they correlate well with the dramatic in vivo reduction of oligodendroglial repopulation observed in experimental autoimmune encephalomyelitis, a model of demyelinating multiple sclerosis (Lin et al., 2006), in which increased IFN $\gamma$ levels occur (Mycko et al., 2003). In contrast, IFN $\beta$, which has been used in the treatment of multiple sclerosis, has been reported as having no effect on the differentiation of wild-type NPs, although an increase in survival was noted after mitogen withdrawal (Hirsch et al., 2009). Thus, elucidating the effects of IFN $\gamma$ during oligodendrogenesis may have important implications for our understanding of the demyelinating processes that occur in inflammatory diseases. In contrast to its effects on neurogenesis and oligodendrogenesis, there was a shift toward astrocyte production in the presence of IFN $\gamma$. These findings are in agreement with previous studies showing that IFN $\gamma$ induces astrocytic proliferation in vitro (Yong et al., 1991; Satoh et al., 1996; Rubio and Torres, 1999). More importantly, however, our results demonstrate that endogenous IFN $\gamma$ affects commitment to the astrocytic lineage.

Interestingly, the inhibitory effect of IFN $\gamma$ on NPs was potentiated in the absence of SVZ-derived microglia, because the effect on neurosphere-forming cells was greater than that on primary SVZ cells. One explanation is that microglia are only retained in the latter population. Thus, although nearly all NPs were responsive to IFN $\gamma$, it appears that microglia confer a protective effect 
on a subpopulation of these cells. This suggests that factors released from microglia block the inhibitory effects of IFN $\gamma$. One possible candidate is IGF-1, which is secreted by activated microglia and is known to be associated with cell renewal, neurogenesis, and neuroprotection (Carro et al., 2001; Lichtenwalner et al., 2001; Aberg et al., 2003). It has also been reported that interleukin-4 induces microglia to secrete IGF-1, thereby overcoming the high-dose IFN $\gamma$-mediated downregulation of IGF-1 expression (Butovsky et al., 2006). Based on the fact that IFN $\gamma$ expression is upregulated (Li et al., 2001) and microglia are activated to proliferate in response to injury-induced inflammation (Schwartz, 2003; Nimmerjahn et al., 2005; Chew et al., 2006), it is possible that microglial protection of NPs from the effects of IFN $\gamma$ may not only constitute part of the natural defense process during neural repair but may also be a factor in maintaining the homeostasis of the neurogenic niche in the healthy brain.

In contrast to the inhibitory effect of IFN $\gamma$ on the adult NP proliferation, our results revealed that IFN $\gamma$ promotes neurosphere formation at E12, although no significant difference was found between $I F N \gamma^{-/-}$and $I F N \gamma^{+/+}$animals. This result accords with the fact that IFN $\gamma$ expression is absent at this time point (Barlow et al., 1984). Thus, IFN $\gamma$ is potentially able to exert a stimulatory effect during embryogenesis in response to inflammation as a result of maternal infection. Moreover, we have provided direct evidence that the stimulatory effect of IFN $\gamma$ on E12 $\mathrm{NP}$ activity is Shh dependent. It has been shown previously that ectopic activation of the Shh signaling pathway leads to hyperproliferation of progenitors (Wechsler-Reya and Scott, 1999), via the classic IFN $\gamma$-receptor-activated Janus kinase/signal transducers and activators of transcription signaling cascade (Campbell, 2005), affecting a number of cell-cycle-related genes (Bennin et al., 2002; Knoepfler and Kenney, 2006). Conversely, blockade of Shh signaling results in the opposite effect (Litingtung and Chiang, 2000; Wijgerde et al., 2002). However, although it has been reported previously that inducible production of IFN $\gamma$ triggers ectopic expression of the Shh gene in developing cerebral granular cells (Wang et al., 2004), the direct action of IFN $\gamma$ on Shh remains to be resolved.

\section{References}

Aberg MA, Aberg ND, Palmer TD, Alborn AM, Carlsson-Skwirut C, Bang P, Rosengren LE, Olsson T, Gage FH, Eriksson PS (2003) IGF-I has a direct proliferative effect in adult hippocampal progenitor cells. Mol Cell Neurosci 24:23-40.

Agresti C, D’Urso D, Levi G (1996) Reversible inhibitory effects of interferon- $\gamma$ and tumour necrosis factor- $\alpha$ on oligodendroglial lineage cell proliferation and differentiation in vitro. Eur J Neurosci 8:1106-1116.

Bailey KA, Drago J, Bartlett PF (1994) Neuronal progenitors identified by their inability to express class I histocompatibility antigens in response to interferon- $\gamma$. J Neurosci Res 39:166-177.

Baka S, Ekonomopoulou MT, Kosmidis C, Efthimiadis C, Iakovidou-Kritsi Z (2009) Cytogenetic effects of recombinant interferon- $\gamma$ on lymphocytes cultures from patients with non-small cell lung cancer. Cancer Genet Cytogenet 193:38-43.

Bansal R, Gard AL, Pfeiffer SE (1988) Stimulation of oligodendrocyte differentiation in culture by growth in the presence of a monoclonal antibody to sulfated glycolipid. J Neurosci Res 21:260-267.

Barlow DP, Randle BJ, Burke DC (1984) Interferon synthesis in the early post-implantation mouse embryo. Differentiation 27:229-235.

Bennin DA, Don AS, Brake T, McKenzie JL, Rosenbaum H, Ortiz L, DePaoliRoach AA, Horne MC (2002) Cyclin G2 associates with protein phosphatase $2 \mathrm{~A}$ catalytic and regulatory $\mathrm{B}^{\prime}$ subunits in active complexes and induces nuclear aberrations and a G1/S phase cell cycle arrest. J Biol Chem 277:27449-27467.
Bogdan C, Schleicher U (2006) Production of interferon- $\gamma$ by myeloid cellsfact or fancy? Trends Immunol 27:282-290.

Bull ND, Bartlett PF (2005) The adult mouse hippocampal progenitor is neurogenic but not a stem cell. J Neurosci 25:10815-10821.

Burke F, East N, Upton C, Patel K, Balkwill FR (1997) Interferon $\gamma$ induces cell cycle arrest and apoptosis in a model of ovarian cancer: enhancement of effect by batimastat. Eur J Cancer 33:1114-1121.

Butovsky O, Ziv Y, Schwartz A, Landa G, Talpalar AE, Pluchino S, Martino G, Schwartz M (2006) Microglia activated by IL-4 or IFN $\gamma$ differentially induce neurogenesis and oligodendrogenesis from adult stem/progenitor cells. Mol Cell Neurosci 31:149-160.

Campbell IL (2005) Cytokine-mediated inflammation, tumorigenesis, and disease-associated JAK/STAT/SOCS signaling circuits in the CNS. Brain Res Brain Res Rev 48:166-177.

Carro E, Trejo JL, Busiguina S, Torres-Aleman I (2001) Circulating insulinlike growth factor I mediates the protective effects of physical exercise against brain insults of different etiology and anatomy. J Neurosci 21:5678-5684.

Chen K, Henry RA, Hughes SM, Connor B (2007) Creating a neurogenic environment: the role of BDNF and FGF2. Mol Cell Neurosci 36:108-120.

Chew LJ, Takanohashi A, Bell M (2006) Microglia and inflammation: impact on developmental brain injuries. Ment Retard Dev Disabil Res Rev 12:105-112.

Cooper MK, Porter JA, Young KE, Beachy PA (1998) Teratogen-mediated inhibition of target tissue response to Shh signaling. Science 280:1603-1607.

De Simone R, Levi G, Aloisi F (1998) Interferon $\gamma$ gene expression in rat central nervous system glial cells. Cytokine 10:418-422.

Doetsch F, García-Verdugo JM, Alvarez-Buylla A (1997) Cellular composition and three-dimensional organization of the subventricular germinal zone in the adult mammalian brain. J Neurosci 17:5046-5061.

Ekdahl CT, Claasen JH, Bonde S, Kokaia Z, Lindvall O (2003) Inflammation is detrimental for neurogenesis in adult brain. Proc Natl Acad Sci U S A 100:13632-13637.

Ekdahl CT, Kokaia Z, Lindvall O (2009) Brain inflammation and adult neurogenesis: the dual role of microglia. Neuroscience 158:1021-1029.

Fuchs E, Tumbar T, Guasch G (2004) Socializing with the neighbors: stem cells and their niche. Cell 116:769-778.

Gough DJ, Levy DE, Johnstone RW, Clarke CJ (2008) IFN $\gamma$ signaling-does it mean JAK-STAT? Cytokine Growth Factor Rev 19:383-394.

Han YG, Spassky N, Romaguera-Ros M, Garcia-Verdugo JM, Aguilar A, Schneider-Maunoury S, Alvarez-Buylla A (2008) Hedgehog signaling and primary cilia are required for the formation of adult neural stem cells. Nat Neurosci 11:277-284.

Harvat BL, Jetten AM (1996) $\gamma$-interferon induces an irreversible growth arrest in mid-G1 in mammary epithelial cells which correlates with a block in hyperphosphorylation of retinoblastoma. Cell Growth Differ 7:289-300.

Hirsch M, Knight J, Tobita M, Soltys J, Panitch H, Mao-Draayer Y (2009) The effect of interferon- $\beta$ on mouse neural progenitor cell survival and differentiation. Biochem Biophys Res Commun 388:181-186.

Holmberg J, Armulik A, Senti KA, Edoff K, Spalding K, Momma S, Cassidy R, Flanagan JG, Frisén J (2005) Ephrin-A2 reverse signaling negatively regulates neural progenitor proliferation and neurogenesis. Genes Dev 19:462-471.

Jiao JW, Feldheim DA, Chen DF (2008) Ephrins as negative regulators of adult neurogenesis in diverse regions of the central nervous system. Proc Natl Acad Sci U S A 105:8778-8883.

Kim SJ, Son TG, Kim K, Park HR, Mattson MP, Lee J (2007) Interferon- $\gamma$ promotes differentiation of neural progenitor cells via the JNK pathway. Neurochem Res 32:1399-1406.

Knoepfler PS, Kenney AM (2006) Neural precursor cycling at sonic speed: N-Myc pedals, GSK-3 brakes. Cell Cycle 5:47-52.

Knudson CM, Tung KS, Tourtellotte WG, Brown GA, Korsmeyer SJ (1995) Bax-deficient mice with lymphoid hyperplasia and male germ cell death. Science 270:96-99.

Kokuzawa J, Yoshimura S, Kitajima H, Shinoda J, Kaku Y, Iwama T, Morishita R, Shimazaki T, Okano H, Kunisada T, Sakai N (2003) Hepatocyte growth factor promotes proliferation and neuronal differentiation of neural stem cells from mouse embryos. Mol Cell Neurosci 24:190-197.

Koo JW, Duman RS (2008) IL-1 $\beta$ is an essential mediator of the antineuro- 
genic and anhedonic effects of stress. Proc Natl Acad Sci U S A 105:751-756.

Kortylewski M, Komyod W, Kauffmann ME, Bosserhoff A, Heinrich PC, Behrmann I (2004) Interferon- $\gamma$-mediated growth regulation of melanoma cells: involvement of STAT1-dependent and STAT1-independent signals. J Invest Dermatol 122:414-422.

Lai K, Kaspar BK, Gage FH, Schaffer DV (2003) Sonic hedgehog regulates adult neural progenitor proliferation in vitro and in vivo. Nat Neurosci 6:21-27.

Leipzig ND, Xu C, Zahir T, Shoichet MS (2010) Functional immobilization of interferon-gamma induces neuronal differentiation of neural stem cells. J Biomed Mater Res A 93:625-633.

Leker RR, Soldner F, Velasco I, Gavin DK, Androutsellis-Theotokis A, McKay RD (2007) Long-lasting regeneration after ischemia in the cerebral cortex. Stroke 38:153-161.

Li HL, Kostulas N, Huang YM, Xiao BG, van der Meide P, Kostulas V, Giedraitas V, Link H (2001) IL-17 and IFN- $\gamma$ mRNA expression is increased in the brain and systemically after permanent middle cerebral artery occlusion in the rat. J Neuroimmunol 116:5-14.

Li X, Tang X, Jablonska B, Aguirre A, Gallo V, Luskin MB (2009) p27(KIP1) regulates neurogenesis in the rostral migratory stream and olfactory bulb of the postnatal mouse. J Neurosci 29:2902-2914.

Lichtenwalner RJ, Forbes ME, Bennett SA, Lynch CD, Sonntag WE, Riddle DR (2001) Intracerebroventricular infusion of insulin-like growth factor-I ameliorates the age-related decline in hippocampal neurogenesis. Neuroscience 107:603-613.

Lin W, Kemper A, Dupree JL, Harding HP, Ron D, Popko B (2006) Interferon- $\gamma$ inhibits central nervous system remyelination through a process modulated by endoplasmic reticulum stress. Brain 129:1306-1318.

Litingtung Y, Chiang C (2000) Specification of ventral neuron types is mediated by an antagonistic interaction between Shh and Gli3. Nat Neurosci 3:979-985.

Liu Z, Fan Y, Won SJ, Neumann M, Hu D, Zhou L, Weinstein PR, Liu J (2007) Chronic treatment with minocycline preserves adult new neurons and reduces functional impairment after focal cerebral ischemia. Stroke 38:146-152.

Lledo PM, Alonso M, Grubb MS (2006) Adult neurogenesis and functional plasticity in neuronal circuits. Nat Rev Neurosci 7:179-193.

Lum M, Croze E, Wagner C, McLenachan S, Mitrovic B, Turnley AM (2009) Inhibition of neurosphere proliferation by IFN $\gamma$ but not IFN $\beta$ is coupled to neuronal differentiation. J Neuroimmunol 206:32-38.

Luskin MB (1993) Restricted proliferation and migration of postnatally generated neurons derived from the forebrain subventricular zone. Neuron 11:173-189.

Magavi SS, Mitchell BD, Szentirmai O, Carter BS, Macklis JD (2005) Adultborn and preexisting olfactory granule neurons undergo distinct experience-dependent modifications of their olfactory responses in vivo. J Neurosci 25:10729-10739.

Mokrý J, Karbanová J, Osterreicher J (2003) Experimental brain injury induces activation of neural stem cells in the forebrain subependyma. Appl Immunohistochem Mol Morphol 11:161-167.

Monje ML, Palmer T (2003) Radiation injury and neurogenesis. Curr Opin Neurol 16:129-134.

Monje ML, Toda H, Palmer TD (2003) Inflammatory blockade restores adult hippocampal neurogenesis. Science 302:1760-1765.

Mouret A, Lepousez G, Gras J, Gabellec MM, Lledo PM (2009) Turnover of newborn olfactory bulb neurons optimizes olfaction. J Neurosci 29: 12302-12314.

Murphy M, Drago J, Bartlett PF (1990) Fibroblast growth factor stimulates the proliferation and differentiation of neural precursor cells in vitro. J Neurosci Res 25:463-475.

Mycko MP, Papoian R, Boschert U, Raine CS, Selmaj KW (2003) cDNA microarray analysis in multiple sclerosis lesions: detection of genes associated with disease activity. Brain 126:1048-1057.

Nakanishi M, Niidome T, Matsuda S, Akaike A, Kihara T, Sugimoto H (2007) Microglia-derived interleukin-6 and leukaemia inhibitory factor promote astrocytic differentiation of neural stem/progenitor cells. Eur J Neurosci 25:649-658.

Nakatomi H, Kuriu T, Okabe S, Yamamoto S, Hatano O, Kawahara N, Tamura A, Kirino T, Nakafuku M (2002) Regeneration of hippocampal pyramidal neurons after ischemic brain injury by recruitment of endogenous neural progenitors. Cell 110:429-441.

Nimmerjahn A, Kirchhoff F, Helmchen F (2005) Resting microglial cells are highly dynamic surveillants of brain parenchyma in vivo. Science 308:1314-1318.

Ninkovic J, Götz M (2007) Signaling in adult neurogenesis: from stem cell niche to neuronal networks. Curr Opin Neurobiol 17:338-344.

Packer MA, Stasiv Y, Benraiss A, Chmielnicki E, Grinberg A, Westphal H, Goldman SA, Enikolopov G (2003) Nitric oxide negatively regulates mammalian adult neurogenesis. Proc Natl Acad Sci U S A 100:95669571.

Palma V, Lim DA, Dahmane N, Sánchez P, Brionne TC, Herzberg CD, Gitton Y, Carleton A, Alvarez-Buylla A, Ruiz i Altaba A (2005) Sonic hedgehog controls stem cell behavior in the postnatal and adult brain. Development 132:335-344.

Platanias LC, Uddin S, Bruno E, Korkmaz M, Ahmad S, Alsayed Y, Van Den Berg D, Druker BJ, Wickrema A, Hoffman R (1999) CrkL and CrkII participate in the generation of the growth inhibitory effects of interferons on primary hematopoietic progenitors. Exp Hematol 27:1315-1321.

Rady PL, Cadet P, Bui TK, Tyring SK, Baron S, Stanton GJ, Hughes TK (1995) Production of interferon $\gamma$ messenger RNA by cells of nonimmune origin. Cytokine 7:793-798.

Ramana CV, Gil MP, Schreiber RD, Stark GR (2002) Stat1-dependent and -independent pathways in IFN- $\gamma$-dependent signaling. Trends Immunol 23:96-101.

Reynolds BA, Tetzlaff W, Weiss S (1992) A multipotent EGF-responsive striatal embryonic progenitor cell produces neurons and astrocytes. J Neurosci 12:4565-4574.

Richards LJ, Kilpatrick TJ, Bartlett PF (1992) De novo generation of neuronal cells from the adult mouse brain. Proc Natl Acad Sci U S A 89:8591-8595.

Rubio N, Torres C (1999) Interferon- $\gamma$ induces proliferation but not apoptosis in murine astrocytes through the differential expression of the myc proto-oncogene family. Brain Res Mol Brain Res 71:104-110.

Sasmono RT, Oceandy D, Pollard JW, Tong W, Pavli P, Wainwright BJ, Ostrowski MC, Himes SR, Hume DA (2003) A macrophage colonystimulating factor receptor-green fluorescent protein transgene is expressed throughout the mononuclear phagocyte system of the mouse. Blood 101:1155-1163.

Satoh J, Paty DW, Kim SU (1996) Counteracting effect of IFN- $\beta$ on IFN- $\gamma$ induced proliferation of human astrocytes in culture. Mult Scler 1:279-287.

Schwartz M (2003) Macrophages and microglia in central nervous system injury: are they helpful or harmful? J Cereb Blood Flow Metab 23:385-394.

Shen Q, Goderie SK, Jin L, Karanth N, Sun Y, Abramova N, Vincent P, Pumiglia K, Temple S (2004) Endothelial cells stimulate self-renewal and expand neurogenesis of neural stem cells. Science 304:1338-1340.

Shingo T, Sorokan ST, Shimazaki T, Weiss S (2001) Erythropoietin regulates the in vitro and in vivo production of neuronal progenitors by mammalian forebrain neural stem cells. J Neurosci 21:9733-9743.

Shou J, Rim PC, Calof AL (1999) BMPs inhibit neurogenesis by a mechanism involving degradation of a transcription factor. Nat Neurosci 2:339-345.

Shyu RY, Su HL, Yu JC, Jiang SY (2000) Direct growth suppressive activity of interferon- $\alpha$ and $-\gamma$ on human gastric cancer cells. J Surg Oncol $75: 122-130$.

Song H, Stevens CF, Gage FH (2002) Astroglia induce neurogenesis from adult neural stem cells. Nature 417:39-44.

Streit WJ, Walter SA, Pennell NA (1999) Reactive microgliosis. Prog Neurobiol 57:563-581.

Sun W, Winseck A, Vinsant S, Park OH, Kim H, Oppenheim RW (2004) Programmed cell death of adult-generated hippocampal neurons is mediated by the proapoptotic gene Bax. J Neurosci 24:11205-11213.

Vallières L, Campbell IL, Gage FH, Sawchenko PE (2002) Reduced hippocampal neurogenesis in adult transgenic mice with chronic astrocytic production of interleukin-6. J Neurosci 22:486-492.

Vivo C, Lévy F, Pilatte Y, Fleury-Feith J, Chrétien P, Monnet I, Kheuang L, Jaurand MC (2001) Control of cell cycle progression in human mesothelioma cells treated with gamma interferon. Oncogene 20:1085-1093. Wallace VA (1999) Purkinje-cell-derived Sonic hedgehog regulates granule 
neuron precursor cell proliferation in the developing mouse cerebellum. Curr Biol 9:445-448.

Walton NM, Sutter BM, Laywell ED, Levkoff LH, Kearns SM, Marshall GP 2nd, Scheffler B, Steindler DA (2006) Microglia instruct subventricular zone neurogenesis. Glia 54:815-825.

Wang J, Lin W, Popko B, Campbell IL (2004) Inducible production of interferon- $\gamma$ in the developing brain causes cerebellar dysplasia with activation of the Sonic hedgehog pathway. Mol Cell Neurosci 27:489-496.

Wechsler-Reya RJ, Scott MP (1999) Control of neuronal precursor proliferation in the cerebellum by Sonic Hedgehog. Neuron 22:103-114.

Wei YP, Kita M, Shinmura K, Yan XQ, Fukuyama R, Fushiki S, Imanishi J (2000) Expression of IFN- $\gamma$ in cerebrovascular endothelial cells from aged mice. J Interferon Cytokine Res 20:403-409.

Wijgerde M, McMahon JA, Rule M, McMahon AP (2002) A direct requirement for Hedgehog signaling for normal specification of all ventral progenitor domains in the presumptive mammalian spinal cord. Genes Dev 16:2849-2864.

Wiltrout C, Lang B, Yan Y, Dempsey RJ, Vemuganti R (2007) Repairing brain after stroke: a review on post-ischemic neurogenesis. Neurochem Int 50:1028-1041.

Wong G, Goldshmit Y, Turnley AM (2004) Interferon- $\gamma$ but not TNF- $\alpha$ promotes neuronal differentiation and neurite outgrowth of murine adult neural stem cells. Exp Neurol 187:171-177.

Yin L, Fu SL, Shi GY, Li Y, Jin JQ, Ma ZW, Lu PH (2008) Expression and regulation of major histocompatibility complex on neural stem cells and their lineages. Stem Cells Dev 17:53-65.

Yong VW, Moumdjian R, Yong FP, Ruijs TC, Freedman MS, Cashman N, Antel JP (1991) $\gamma$-interferon promotes proliferation of adult human astrocytes in vitro and reactive gliosis in the adult mouse brain in vivo. Proc Natl Acad Sci U S A 88:7016-7020. 